\title{
Transition Metal Oxides and Their Composites for Photocatalytic Dye Degradation
}

\author{
Preety Ahuja ${ }^{1}$, Sanjeev Kumar Ujjain ${ }^{1, *}$, Rajni Kanojia ${ }^{2}$ and Pankaj Attri ${ }^{3} \mathbb{C}$ \\ 1 Research Initiative for Supra-Materials, Shinshu University, Nagano City 380-8553, Japan; \\ drpreetyahuja@gmail.com \\ 2 Department of Chemistry, Shivaji College, University of Delhi, Delhi 110027, India; drrajnikanojia@gmail.com \\ 3 Center of Plasma Nano-Interface Engineering, Kyushu University, Fukuoka 819-0395, Japan; \\ chem.pankaj@gmail.com \\ * Correspondence: drsanjeevkujjain@gmail.com
}

Citation: Ahuja, P.; Ujjain, S.K.;

Kanojia, R.; Attri, P. Transition Metal

Oxides and Their Composites for Photocatalytic Dye Degradation. J. Compos. Sci. 2021, 5, 82. https:// doi.org/10.3390/jcs5030082

Academic Editor:

Francesco Tornabene

Received: 18 February 2021

Accepted: 12 March 2021

Published: 15 March 2021

Publisher's Note: MDPI stays neutral with regard to jurisdictional claims in published maps and institutional affiliations.

Copyright: (c) 2021 by the authors. Licensee MDPI, Basel, Switzerland. This article is an open access article distributed under the terms and conditions of the Creative Commons Attribution (CC BY) license (https:// creativecommons.org/licenses/by/ $4.0 /)$

\begin{abstract}
Transition metal oxides (TMO) and their carbon composites have become a glittering upcoming material science candidate. Their interesting properties, such as their meticulous morphology, plentiful availability, flexible surface chemistry along with outstanding mechanical, thermal, and optical properties make them ideal for efficient photocatalytic dye degradation. An extensive range of TMO, and their carbon composites are reviewed highlighting the progression and opportunities for the photocatalytic degradation of dyes. Here, we concisely describe the numerous techniques to extend the optical absorption of these TMOs involving dye sensitization, metal doping, etc. Besides this, an overview of all aspects of dye degradation along with the prevailing challenges for future utilization and development of such nanocomposites towards highly efficient dye degradation system are also reported.
\end{abstract}

Keywords: transition metal oxide; bimetallic transition metal oxide; carbon composite; photocatalytic; dye degradation

\section{Introduction}

With the increase in world population and rapid urbanization, natural resources are getting exhausted. Development of urban areas causes organic effluents from industries and agricultural activities, which not only cause threatens to human lives but also affected aquatic life very adversely [1]. Globally, 1.2 billion people are deficient in accessing safe drinking water, and millions die from uncontrolled spread of diseases and chronic illness transmitted via unsafe water [2,3]. Particularly, there is an explosive development in the dye and dyeing industries since last few decades. As effluents, many potentially hazardous compounds have been introduced into the environment, which are harmful for both flora and fauna on the planet. As per the World Bank's estimation, textile dyeing and treatment effluents results in 17 to $20 \%$ of water pollution [4]. The affecting factors broadly comprise of poor biodegradable waste such as used dyes and of which $\sim 10-15 \%$ enter the environment through wastes. These dyes can be cationic, anionic or non-ionic depending on their chemical structure. The release of dyes in effluent results in perturbations of the marine life leading to severe effects on exposed organisms owing to the reduction in photosynthetic rate.

Moreover, water quality is significantly influenced due to the color of the dye, causing esthetic pollution, which is associated with contamination [5,6]. Willmott et al. has reported that dye concentrations as small as $0.005 \mathrm{mg} \mathrm{dm}^{-3}$ is perceptible in river water [7]. Today, $20 \%$ of our population has no access to safe water, $40 \%$ suffers owing to improper sanitary conditions and millions of people die every year from diseases communicated through unsafe water [2,8]. Dye effluent commonly contains chemicals which are toxic, carcinogenic or mutagenic to aquatic species $[9,10]$. In addition, human disorders say nausea, hemorrhage, 
ulceration of the skin and mucous membranes [11] are caused due to the existence of dyes or their degradation products in water. Along with this, these dyes can also cause acute injury to the central nervous system and reproductive system [12]. This leads to deeper concern for colored wastewater discharges and convincing the dye users to espouse cleaner technology methodologies for benign dyeing strategies and upgrading dyes fatigue.

Consequently, significant efforts have been employed to initiate different suitable purification methods to destroy these pollutants. However, their incomplete removal during processing led to their presence in wastewater effluents in minute amount which is a matter of big concern towards the health and wealth of ecosystem, as they have endocrine disrupting potency [13].

Modernized society demands for pure water have made degradation of the dyes a great challenge that needs to be addressed for the well-being of humans and aquatic life. Several physical, biological and chemical techniques have been utilized for water purification (Figure 1). Adsorption and ion exchange are the most widely used physical methods for dyes removal resulting in high quality water [14]. However, the most commonly used adsorbents such as activated carbon have a high cost and hence replaced by other alternatives which demonstrate good efficiency $[15,16]$. Further, this method transfers pollutants to other phases that need to be treated. Another method involves coagulation/flocculation for color removal from textile effluents is associated with high-cost reagents, which impedes their practicability. Separation processes by utilizing membranes, reverse osmosis and ultrafiltration with microfiltration help detach the dyes from larger molecules in the wastewater. These processes have limited applications due to the inherent limitations, such as high expenditure, limited versatility, elevated salt content in the waste matter, replacement of membranes and problems associated with the disposal.

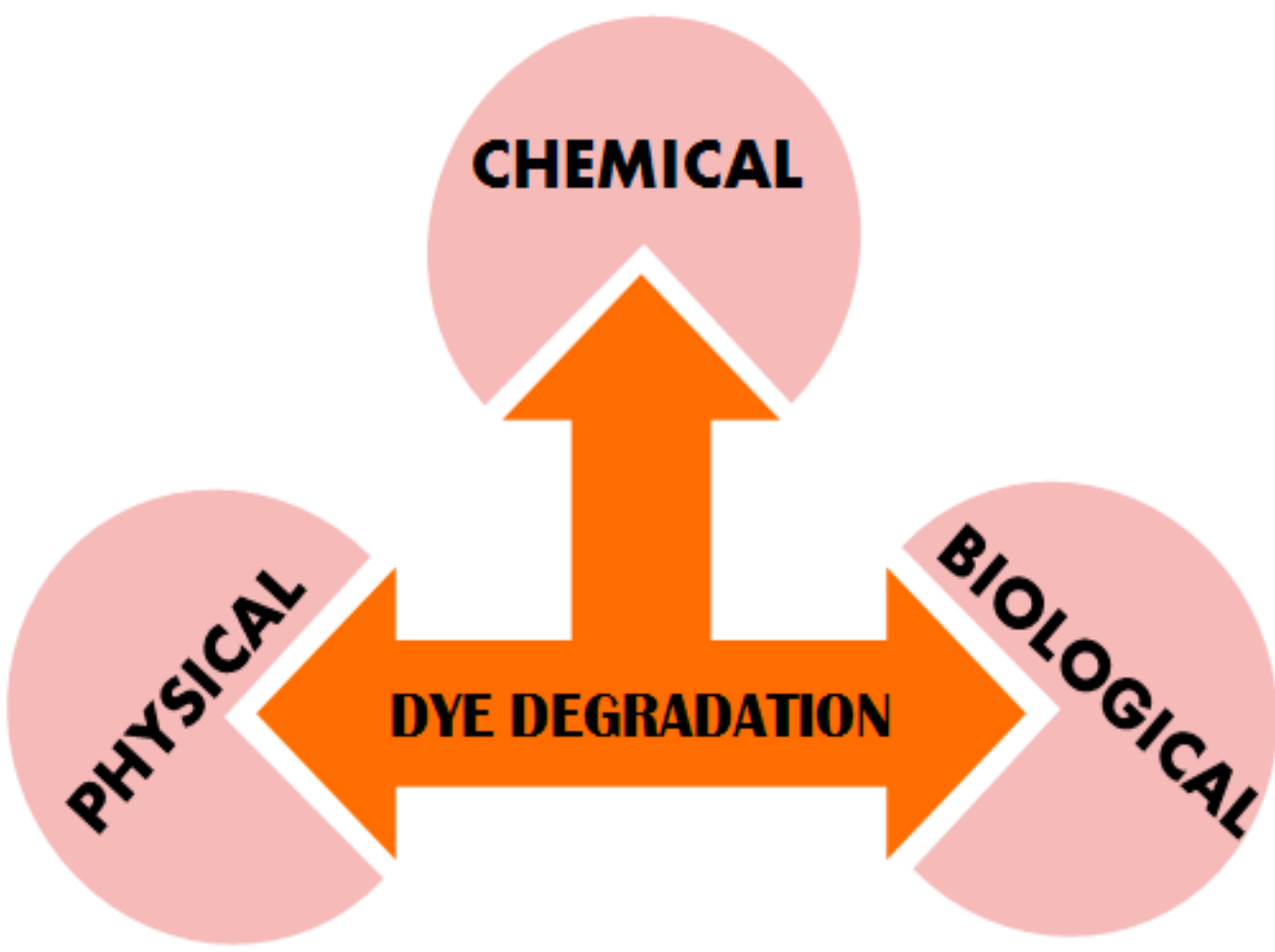

Figure 1. Different ways of dye degradation constitute the Physical, Chemical and Biological approaches.

Utilization of biological methods proved to be an economical alternative since it requires minimal major processing costs, but numerous dyes are deliberated to defy microbial attack. Different bacteria and fungi have been used to treat textile effluents via various biological processes [17-22]. Two conditions, aerobic and anaerobic, have been combined for the proficient removal of azo dyes from wastewater, as azo dyes are not efficiently metabolized under aerobic conditions. In contrast, biological enzymes under anaerobic 
conditions utilize a high reduction rate of electrophilic azo-bond of the dye molecule to produce colorless aromatic amines [23]. Such amines are resilient to further anaerobic mineralization and are sometimes mutagenic to animals. Lourenco et al. suggested a sequential anaerobic-aerobic scheme utilized for wastewater treatment involving mineralization of the amines under aerobic environments via hydroxylation pathway with the ring-opening procedure [24]. Furthermore, the use of whole cells instead of enzymes has been given preference for the degradation of dyes in wastewater since cells can protect the enzymes from the severe environment. However, due to their complex structure with different chromophoric groups, dyes are enormously recalcitrant [23]. In addition, the frequent daily unpredictability of features of such wastewater enhances the difficulty of treatment [25]. Although several known physical and biological methodologies have been extensively utilized for decolorization [26], no one has materialized by way of complete remediation. Wastewater treatment via microbial biocatalysts offers potential advantages over different physical processes, but biological methods are rather inefficient, whereas physical methods are impeded in the operation scale.

Consequently, various chemical processing, such as chemical oxidation, solvent extraction, catalytic degradation, etc. for water purification, emerged. However, these are time consuming and high on cost hindering their practical utility. To provide a wholesome remediation, nanotechnology is the potential approach, focusing on unique attributes of materials emerging from nano dimensions that ensure the purification of water resources. This is possible through photocatalysis, a property exhibited by semiconducting oxides or more precisely transition metal oxides (TMO), whereby they absorb photons to undergo redox reactions, breaking complex organic molecules into simpler fragments [27]. The diffusion length of charged carriers $\left(\mathrm{e}^{-} / \mathrm{h}^{+}\right)$from bulk to surface is significantly reduced for nanoparticles facilitating these carriers' migration rate and hence enhancing the photoactivity. TMOs such as titanium dioxide $\left(\mathrm{TiO}_{2}\right)$, zinc oxide $(\mathrm{ZnO})$, iron oxide $\left(\mathrm{Fe}_{2} \mathrm{O}_{3}\right)$ and magnesium oxide $(\mathrm{MgO})$ have been explored extensively in photocatalytic applications for water remediation [28,29]. Among them, the most widely utilized is $\mathrm{TiO}_{2}$ owing to photochemical stability, chemical inertness, and ecologically benign [30]. In addition, its competitive rival, $\mathrm{ZnO}$, has better electron mobility [31]. Even though they show excellent properties, their application in photocatalytic degradation (UV light driven) is hindered owing to wide band gap. Hence, band gap modification is required for improving the photodegradation efficiency, which will be more comprehensively discussed in later section.

Currently, nanotechnology-based water purification involves photocatalytic dye degradation mainly focusing on three major areas for efficient performance:

i. Visible light-driven photocatalyst

ii. High adsorption capacity

iii. Large electron/hole recombination lifetimes

Due to the wideband gaps of the transition metal oxides, extensive research has been employed to redshift their band gaps towards visible light-driven photocatalysis. Besides, the higher bandgap, rapid electron/hole pair recombination further impedes the photocatalytic activity. This may arise due to low adsorption capacity of existing adsorbent, causing a significant bottleneck for dye mineralization [32,33].

In order to achieve the above-mentioned goals, two approaches are typically employed which are the doping of existing transition metal oxides with foreign transition metal ion to tune the band gap and hence, altering the optical absorption of the resulting nanocomposite. Introduction of foreign transition metal ions results in formation of spinel or mixed bimetallic transition metal oxides. Furthermore, co-adsorbents serve the purpose to enhance the adsorption capacity with larger electron/hole recombination lifetime. High adsorption capacity is achieved by the co-adsorbent, which will facilitate the charge transfer processes resulting in higher efficiency [32,33]. 
Besides, the large volume of literature assembled by the researchers, here we offer a concise insight of the research on efficient photo dye degradation via transition metal oxide-based composites, along with the latest drift towards photocatalytic studies.

\section{Dye Degradation}

Solids, in general, possess different band gaps which result in diverse properties. Based on varying bandwidths, they are classified as metals, insulators and semiconductors (Figure 2). Solids (like metals), have overlapped band gap regardless of the temperature. The higher band is the conduction band whereas the lower one is the valence band and possesses gap for semiconductors and insulators. Bandgap in insulators is very high, and hence it is difficult to excite electrons from the valence to conduction band, and the gap is called the forbidden gap. However, in semiconductors, the bandgap is small enough for the electrons to promote from valence to conduction band at room temperature. Their bandgap lies in the range of 0 to $7 \mathrm{eV}$ bounding energy levels in the visible and UV light [34,35]. Photocatalysis involves light irradiation on the catalyst which functions as thermal energy and hence excites the electron from the valence to conduction band of the catalyst. Therefore, the band gap's width is the primary requisite for efficient photocatalyst, which strongly influences the electrical and optical characteristics of the material. To utilize the light from the solar spectrum, band gap engineering is the fundamental approach operated for semiconducting materials, and hence they are broadly utilized as photocatalysts.

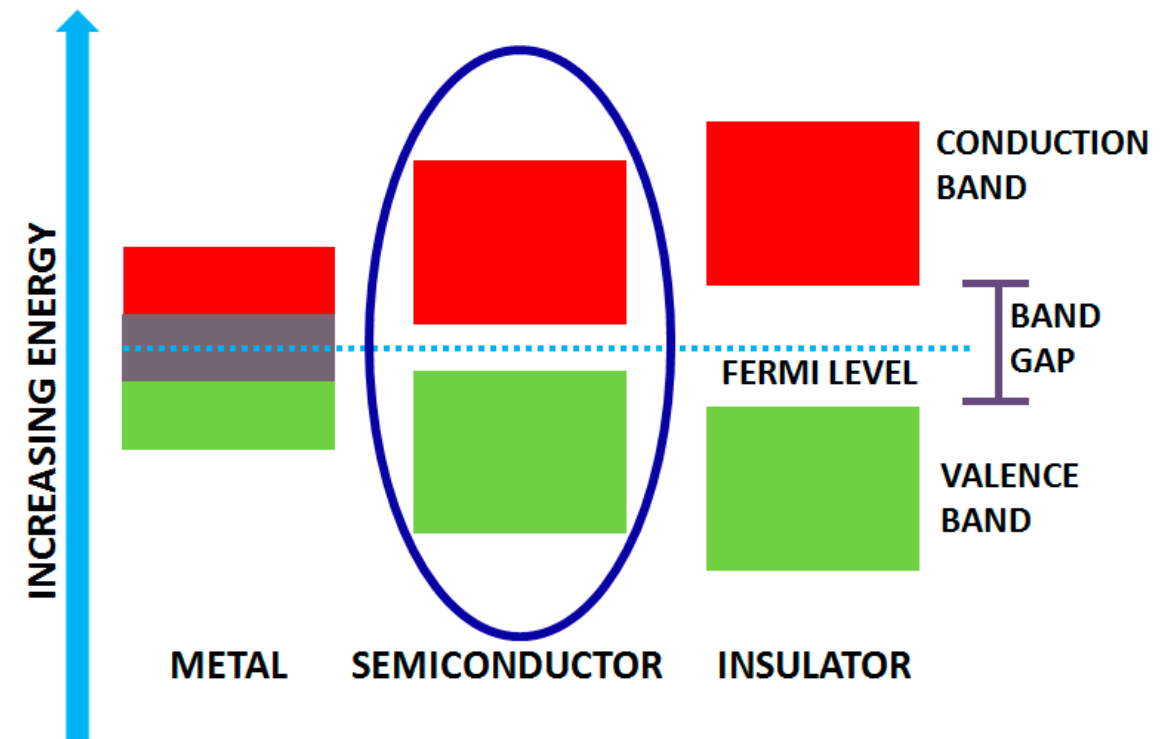

Figure 2. Band gap structure for metals, semiconductors and insulators.

In the photocatalytic dye degradation, contaminants are destroyed utilizing transition metal oxides as efficient adsorbents, light source and oxidizing agent such as air/oxygen. Absorption of photons (with energy $\geq$ the band gap between valence and conduction band of transition metal oxide) results in electron transition from the valence band to the conduction band resulting in the formation of hole $\left(\mathrm{h}^{+}\right)$in the valence band and electron $\left(\mathrm{e}^{-}\right)$in the conduction band (Figure 3$)$. Oxygen adsorbed on the photocatalyst is reduced by the electron in the conduction band, whereas the hole oxidizes the pollutant or sometimes it oxidizes water to produce ${ }^{\bullet} \mathrm{OH}$ radicals. Here, $\mathrm{h}^{+}$and $\mathrm{e}^{-}$act as oxidizing and reducing agents, respectively [32]. When reduction and oxidation do not proceed concurrently, electrons accumulate in the conduction band resulting in fast recombination of electrons and holes, reducing photonic efficiency. Hence, their consumption is a vital requirement to endorse photocatalytic performance. Various parameters such as light intensity, catalyst loading, $\mathrm{pH}$, type of adsorbent, contaminant (dye) type and concentration etc. influences 
photocatalytic dye degradation [33]. Among them, this article concentrates on adsorbent properties, favorable for photo dye degradation with high efficiency.

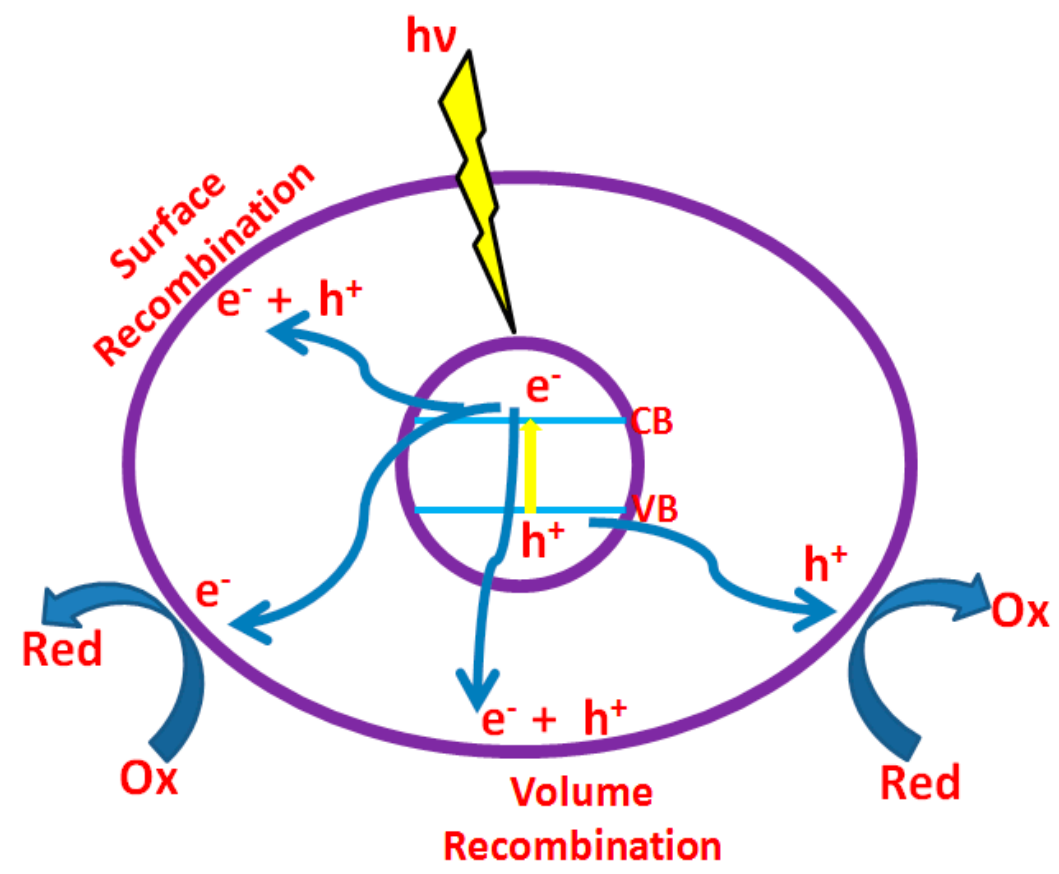

Figure 3. Different processes (reduction, oxidation, surface recombination, etc.) takes place after irradiation of photocatalyst.

\section{Nanocomposites for Photocatalytic Dye Degradation}

\subsection{Transition Metal Oxides as Photocatalyst}

Chemical reactions in the water system are greatly influenced by the light (visible and UV light). Most of the semiconductors can strongly interact with the photons' wavelengths as their band gaps lie in the same range. In addition to this, the large bandgap of these materials results in the absorption of UV light limiting their practical application because UV light only constitutes $5 \%$ of the solar spectrum. Besides suitable bandgap, potential adsorbents should be easy to produce, cost-effective, photostable and non-toxic for the environment $[36,37]$. The researchers have also explored numerous other techniques to extend the optical absorption of these transition metal oxides involving dye sensitization, metal doping, semiconductor coupling and non-metal deposition [38-44]. The purposes for utilizing these techniques are as follows:

i. Enhance adsorption capacity at the catalyst surface

ii. Tuning the optical band gap or light absorption capability of the photocatalyst

iii. Preventing the recombination of charged carriers in combination with facilitated charge transfer

This section emphasizes the recent advances in various types of metal oxide nanoparticles and their composites for photocatalytic dye degradation from the wastewater.

\subsubsection{Dye Degradation by Titanium Oxides}

Photocatalytic reactions firstly reported by Fujishima and Honda et al. on the surface of $\mathrm{TiO}_{2}$ (photocatalyst) which are photolysis of water, as shown below [45]:

$$
\begin{aligned}
\mathrm{TiO}_{2}+\mathrm{hv} & \rightarrow \mathrm{h}^{+}+\mathrm{e}^{-} \\
\frac{1}{2} \mathrm{H}_{2} \mathrm{O}+\mathrm{h}^{+} & \rightarrow \frac{1}{2} \mathrm{O}_{2}+\mathrm{H}^{+} \\
\mathrm{H}^{+}+\mathrm{e}^{-} & \rightarrow \frac{1}{2} \mathrm{H}_{2}
\end{aligned}
$$


Here, $\mathrm{H}_{2}$ gas is produced from water and light interaction from solar spectrum (visible and UV), which can act as an alternative to fossil fuels [46,47]. It was then noted that the intermediate reactions resulted in formation of $\mathrm{OH}$ radicals, and hence, photocatalysis becomes important for the decomposition of water pollutants [48,49]. Researchers later focus on improving the efficiency of the involved photocatalysts (semiconducting oxides) for degradation of contaminants to purify water.

Earlier numerous studies have been reported for various photocatalyst, which produces photo excited $\mathrm{e}^{-} / \mathrm{h}^{+}$pair for the decomposition of dyes. Among existing materials, $\mathrm{TiO}_{2}$ proved to be the most active photocatalyst for dye degradation $[38,50]$.

An outstanding review on metal doping for photocatalysis is reported by Carp et al. [37] with the main objective of reducing the band gap of the photocatalyst and the generation of intra-states between valence and conduction band resulting in UV to visible light absorption. The doped ion alters the recombination rate by acting as a trapping center for charge carrier and modifying the surface properties by enhancing adsorption capacity. Silver (Ag) nanoparticles loaded on different semiconductors have been illustrated as an effective approach for improving photocatalytic performance [51,52]. The metallic nanoparticle of $\mathrm{Ag}$ acts as a sink to accept the photoexcited electrons facilitating the reduction process and decelerating electron/hole recombination. Ag nanoparticles have also been utilized to tune metal oxide properties, i.e., $\mathrm{TiO}_{2}, \mathrm{NiO}$ and $\mathrm{ZnO}$ by surface plasmon resonance [42]. Excited by this, a number of research groups have explored the doping of $\mathrm{TiO}_{2}$ by different transition metal ions [53-55]. Vanadium doped $\mathrm{TiO}_{2}$ active under visible light illumination was reported by Klosek et al. After irradiation by visible light, excited vanadium donates an electron to $\mathrm{TiO}_{2}$ conduction band promoting the oxidation of surface adsorbed molecules [56]. Boron-doped photocatalyst has also been explored and displays high performance in mineralization of Methyl orange (MO) with decolorization degree of $90 \%$ in 2 min [57]. Alternatively, non-metal doping results in redshift of the energy which is absorbed by the photocatalyst, resulting from bandgap narrowing in which valence band is elevated (Figure 4), with no modification in the conduction band $[34,49,58]$.

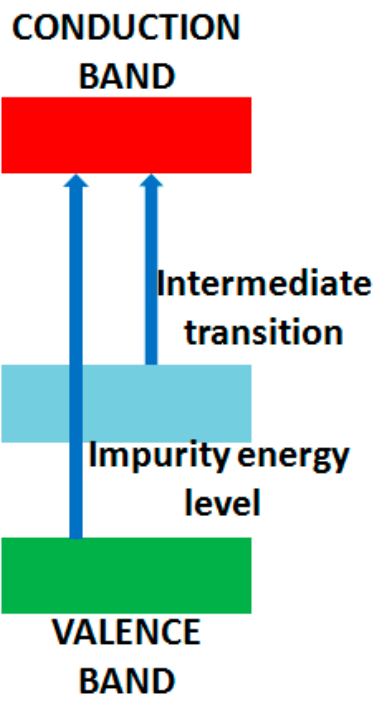

\section{METAL ION DOPING}

\section{CONDUCTION}

BAND

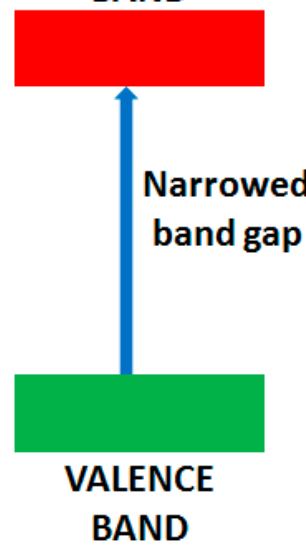

NON-METAL COMPOSITES

Figure 4. Modification of band gaps on metal ion doping and for non-metal composite.

Doping of rare earth metal ions also enhances the potential of photocatalytic dye degradation owing to their distinctive chemical, physical and electronic properties. Associated $f$-orbital of the lanthanide ions has increased absorption of pollutants via Lewis base interaction and function as an efficient electron trapper. Du et al. suggested that doping $\mathrm{TiO}_{2}$ with rare earth metal ion enhances its photocatalytic performance [59]. Ce doping 
(1\%) in $\mathrm{TiO}_{2}$ was reported to display best decolorization performance of Methylene Blue (MB). Zhu et al. reported $91.2 \%$ decolorization efficiency for $\mathrm{MB}$ by $\mathrm{Ce}^{+3}$ doped $\mathrm{TiO}_{2}-\mathrm{SiO}_{2}$ after 180 min irradiation [60].

In addition, there also exist reports on simultaneous deposition and doping, $\mathrm{Ag} / \mathrm{Ag}(\mathrm{I})$ $\mathrm{TiO}_{2}$ in which $\mathrm{Ag}(\mathrm{I})$ doping come up with the development of an isolated energy level of $\mathrm{Ag} 4 \mathrm{~d}$ in $\mathrm{TiO}_{2}$ bandgap [61]. Visible light illumination resulted in the absorption of visible light by isolated energy level of $4 \mathrm{~d}$. In contrast, the surface metallic Ag facilitates the photogenerated carriers (electrons and holes) separation resulting in higher visible light activity than the $\mathrm{TiO}_{2}$ modified with Ag.

Another alternative to improve the visible light absorption or narrowing the bandgap is to substitute oxygen with inorganic ions $\left(\mathrm{C}^{+4}, \mathrm{~S}^{-2}\right.$, etc.). Different methods have been used to produce visible light active $\mathrm{TiO}_{2-\mathrm{x}} \mathrm{N}_{\mathrm{x}}$ photocatalyst along with the shift of absorption edge [62-67]. It is predicted to lower the bandgap energy because N2p states of dopant mix with the $\mathrm{O} 2 \mathrm{p}$ resulting in the narrow bandgap. Moreover, $\mathrm{TiO}_{2}$ oxygen sites replaced by nitrogen form isolated impurity energy levels above valence band, which will also narrow the bandgap. Strongly localized N2p states above the valence band (isolated empty states) incline to trap the photogenerated electrons, thus decreasing the photocurrent [68].

\subsubsection{Dye Degradation by Zinc Oxides}

In addition to $\mathrm{TiO}_{2}$, Zinc oxide is a promising adsorbent for wastewater dye degradation owing to its low cost, non-toxicity and tunable morphological features. Daneshvar et al. reported a suitable alternative, $\mathrm{ZnO}_{2}$ with similar photocatalysis mechanism as that of $\mathrm{TiO}_{2}$ [69]. Notably, tunable morphology of $\mathrm{ZnO}$ also played crucial role in wastewater remediation. The $\mathrm{ZnO}$ hierarchical mesoporous microspheres displayed remarkably high adsorption capacity $\left(334 \mathrm{mg} \mathrm{g}^{-1}\right.$ ) for Congo red dye in comparison with the commercially available $\mathrm{ZnO}$ powder [70]. Hollow microsphere of $\mathrm{ZnO}-\mathrm{ZIF}-8$ [ $\mathrm{Zn}\left(\mathrm{MeIM}_{2}\right)$ ] has also been explored for dye adsorption and reported with further enhanced efficiency by the core-shell structure of the resulting composite [71]. Recently, green synthesis of $\mathrm{ZnO}$ has attracted extensive attention as a feasible, highly efficient and eco-friendly protocol to eliminate the environmental impact of commonly utilized synthesis methods in laboratory. The Panos extract mediated quaker ladies type $\mathrm{ZnO}$ nano flower ( $\mathrm{ZnO} / \mathrm{QNF}$ ) degraded the $15 \mathrm{mg} \mathrm{L}^{-1} \mathrm{MB}$, Eosin Y (EY) and Malachite green (MG) to >99\% within 80, 90 and $110 \mathrm{~min}$, respectively [72]. $\mathrm{ZnO}$ nanoparticles synthesized using the Calliandra hematocephala leaf extract shows $88 \% \mathrm{MB}$ degradation, under solar radiation in $270 \mathrm{~min}$ [73], while $\mathrm{ZnO}$ nanoparticles obtained using Quince seed Mucilage as stabilizing agent displays $80 \%$ degradation of $\mathrm{MB}$ within $2 \mathrm{~h}$ [74]. Furthermore, $\mathrm{ZnO}$ nanoparticles synthesized via extracellular culture filtrates of Aspergillus niger degraded the Bismarck brown dye with $90 \%$ efficiency [75]. Additionally, $\mathrm{Cr}$-doped $\mathrm{ZnO}$ with different amount of $\mathrm{Cr}^{3+}$ were reported for the removing anionic dyes by enhancing the surface defects on $\mathrm{ZnO}$ nanoparticles. This correspondingly resulted in formation of hydroxyl groups for the protonation leading to positive charge generation. This positively charged $\mathrm{ZnO}$ nanoparticles undergo strong electrostatic interaction and selectively eliminate the anionic dyes driven by photocatalysis [76].

\subsubsection{Dye Degradation by Iron Oxides}

Extensive availability of iron oxide is further reported with large photocatalytic activity. Advantageously, their recovery from the system owing to the inherent magnetic effect endow a promising adsorbent alternative. Photocatalytic degradation features of iron oxides $\left(\mathrm{Fe}^{+3}\right)$ in different forms such as $\alpha-\mathrm{Fe}_{2} \mathrm{O}_{3}, \gamma-\mathrm{Fe}_{2} \mathrm{O}_{3}, \alpha-\mathrm{FeOOH}, \beta-\mathrm{FeOOH}$, and $\gamma$-FeOOH were explored for the visible range dye degradation. Further, azo dyes are demineralized by iron oxide powder, resulting in substituted benzene and naphthalene as degraded products [77]. Optimized crystallite size $(35,100,150 \mathrm{~nm})$ of the iron oxide nanoparticles were also demonstrated to successfully degrade Congo red. Notably, the Congo red was degraded in presence and absence of visible light using the $35 \mathrm{~nm}$ nanopar- 
ticles with no distinct effect on the photocatalytic decomposition [78]. The addition of $\mathrm{Zn}^{2+}$ and $\mathrm{Al}^{3+}$ to the hydrothermal reaction system resulted in the formation of iron oxides with cubic and disc structures, respectively, which successfully degraded Rhodamine $\mathrm{B}$ (RB) in the presence of $30 \% \mathrm{H}_{2} \mathrm{O}_{2}$ solution. The photodegradation processes amplified significantly with increasing amount of $\mathrm{H}_{2} \mathrm{O}_{2}$ which facilitate diffusion onto the iron oxide surface enhancing the generation of reactive ${ }^{\bullet} \mathrm{OH}$ [79]. Additionally, Shenoy et al. studied the effect of morphology-dependent surface charges of iron oxide for the visible light photocatalytic degradation of MB. The nanorods morphology with high negative surface charges $(-20.8 \mathrm{mV})$ showed $\sim 86 \% \mathrm{MB}$ degradation, which outperformed other morphologies like hexagonal, oval and agglomerated nanoparticles [80]. Furthermore, iron oxide nanoparticles synthesized via various green routes also demonstrated high degradation efficiency. Teucrium polium leaf extract synthesized iron oxide nanoparticles (IONPs) degraded the $\mathrm{MO}$ dye with $73.6 \%$ efficiency in a $6 \mathrm{~h}$ reaction [81], while, magnetic $\alpha-\mathrm{Fe}_{2} \mathrm{O}_{3}$ nanoparticles synthesized using Cynometra ramiflora fruit extract demonstrated $94 \%$ degradation of MB in $110 \mathrm{~min}$, under sunlight irradiation [82]. Iron oxide nanoparticles synthesized using pomegranate (Punica granatum) seeds extract also possesses $95 \%$ reactive blue dye degradation under UV light irradiation for $56 \mathrm{~min}$ [83]. However, rod-like $\mathrm{Fe}_{2} \mathrm{O}_{3}$ magnetic nanoparticles synthesized using the Peltophorum pterocarpum leaf extract could achieve $92 \% \mathrm{MB}$ degradation in minimum $27 \mathrm{~min}$. This rapid degradation has been related to the "electron relay process" in which $\mathrm{BH}_{4}{ }^{-}$ions generated from $\mathrm{NaBH}_{4}$ transfer electrons to $\mathrm{Fe}_{2} \mathrm{O}_{3}$ nanoparticles generating a negatively charged environment to degrade the $\mathrm{MB}$ dye to harmless products [84]. Such green synthesized nanoparticles can potentially serve as an efficient catalyst for environmental remediation. Different metal doping in iron oxide alters the recombination process of charge carriers and augments the photocatalytic activity. Different $\mathrm{Au}$ loadings in $\mathrm{Au}-\mathrm{Fe}_{2} \mathrm{O}_{3}$ aerogels were utilized as photocatalysts for mineralization of Disperse Blue 79 dye. This correspondingly promoted the accumulation of the photogenerated electrons and delayed charge carrier recombination, improving the efficiency [85].

\subsubsection{Dye Degradation by Other Oxides}

Various photocatalysts like CdS, GaAs and $\mathrm{PbS}$ are not stable since they undergo photocorrosion besides their toxicity [36,86]. Additionally, the low charge separation efficiency of photoexcited carriers in $\mathrm{TiO}_{2}$ impeded its applicability [87]. So, several other TMOs involving $\mathrm{MnO}_{2}, \mathrm{CuO}_{2}, \mathrm{Ag}_{2} \mathrm{O}$ modified $\mathrm{MoS}_{2}$ etc. are explored as photocatalyst. $\mathrm{MnO}_{2}$ nanosheets modified with fiber glass was developed by Zhang et al. [88] and explored for mineralization of $\mathrm{MB}$ at different $\mathrm{pH}$ with efficiency $>95 \%$. Pandit et al. reported colloidal $\mathrm{MnO}_{2}$ catalyzed degradation of methyl red and $\mathrm{MO}$ dye with high efficiency [89]. Besides colloidal form, mesoporous $\mathrm{MnO}_{2}$ also exhibits superb performance for $\mathrm{MB}$ mineralization in $\mathrm{H}_{2} \mathrm{O}_{2}$ at neutral $\mathrm{pH}$ and it can be recycled with tiny decrement of catalytic activity at room temperature [90].

Dyes are also used as sensitizers in the visible region including erythrosine $B$, thionine, rhodamine and ruthenium trisbipyridine [91-94]. Dye sensitization process involves indirect electron injection from the excited dye rather than the photocatalyst. Firstly, dye gets excited to singlet and triplet states followed by conversion to dye radicals. Electrons are then injected to the photocatalyst conduction band and interact with the adsorbed oxygen [95]. In addition to this, photocatalytic activity can be enhanced by coupling two semiconductors with different bandgaps providing more efficient separation of charged carriers and extended light absorption range [96-98]. Ternary nanocomposite $\mathrm{Cu}_{2} \mathrm{O}-\mathrm{BiVO}_{4}$ $\mathrm{WO}_{3}$ has also been explored and showed augmented photocatalytic activity compared to their pristine components due to better charge separation [99].

$\mathrm{Ag}_{2} \mathrm{O}$ nanorods modified $\mathrm{MoS}_{2}$ microflowers $\left(\mathrm{Ag}_{2} \mathrm{O} / \mathrm{MoS}_{2}\right)$ based heterostructures exhibited ten times larger photocatalytic efficiency. This is ascribed to consequent morphology and enhanced charge separation efficiency resulting from synergistic effects [100]. 
Effect of different oxidants like peroxymonosulphate (PMS), peroxydisulphate (PDS) and hydrogen peroxide $\left(\mathrm{H}_{2} \mathrm{O}_{2}\right)$ on photocatalysis had been further explored by utilizing different adsorbents [38]. Peroxydisulphate (PDS) showed the off-putting effect on MB demineralization, whereas $\mathrm{H}_{2} \mathrm{O}_{2}$ and peroxymonosulphate (PMS) enhances the degradation rate.

\subsection{Bimetallic Transition Metal Oxides as Photocatalyst}

Visible light-driven photocatalyst are the ideal alternative as solar energy constitutes $43 \%$ of the visible light. Monometallic oxides, their reduced counterparts or noble metal doped derivatives have been utilized in $\mathrm{MB}$ degradation under visible light, however, their efficiency is impeded by light absorption characteristics [101-104]. This can be made in our favor by tailoring the band gap of the resulting composite, which will alter the composite's light absorption feature. Hence, bandgap engineering is a vital requirement for high efficiency of the adsorbent in photo dye degradation. Doping with other transition metal oxide is a typical approach resulting in energy states' generation between valence and conduction band for electronic transitions due to photoexcitation [105]. Mahmood et al. reported that optimum doping of $\mathrm{Mn}^{+2}$ in $\mathrm{ZnO}$ enhances its photocatalytic activity by narrowing its bandgap [106]. Further, Deka et al. reported the tuning of bandgap of $\mathrm{ZnO}$ with Mn content $\left(\mathrm{Zn}_{1-\mathrm{x}} \mathrm{Mn}_{\mathrm{x}} \mathrm{O}\right.$ with $\left.\mathrm{x}=0.02,0.05\right)$ which resulted in varying performance [107]. The photocatalyst's effective performance also depends on various other parameters say $\mathrm{pH}$, dye concentration, light intensity etc. which have been explored by investigating the influence of these factors on the rate of photoactive dye degradation utilizing $\mathrm{CeCr}_{2} \mathrm{O}_{5}$ as photocatalyst [108]. With the increase in dye concentration, the photocatalytic rate first increases and then decreases. This phenomenon arises because more dye molecules are available for degradation with the increase in dye concentration, consequently enhancing the rate. After a certain dye concentration, rate declines. This is attributed to the dye's filtering action where it acts as filter for incident light, inhibiting the desired light intensity to approach the semiconductor surface.

$\mathrm{CeO}_{2}$ acts as a promoter for $\mathrm{Fe}_{2} \mathrm{O}_{3} / \gamma-\mathrm{Al}_{2} \mathrm{O}_{3}$ has been explored by Liu et al. [109] for photocatalytic azo dye degradation. They concluded that doping of $\mathrm{CeO}_{2}$ results in efficient dispersion and smaller particle size of $\mathrm{Fe}_{2} \mathrm{O}_{3}$ presenting more active sites. Further, $\mathrm{CeO}_{2}$ presence increases the chemisorption of oxygen, thereby improving the redox properties of the photocatalyst. $\mathrm{CeO}_{2}$ is also doped in $\mathrm{ZnO}$ by Saravanan et al., and the resulting composite is found to exhibit improved photodegradation rate as compared to $\mathrm{ZnO}$ [110]. $\mathrm{CeO}_{2}$ nanoparticles, owing to their lower bandgap, show enhanced photoactivity of the composite on visible light irradiation. This enhancement on visible illumination is attributed to $\mathrm{CeO}_{2}$ nanoparticles, which capture the electrons with hydroxyl radical formation from the holes and, hence, prevent the electron/hole recombination. In addition, the composite shows efficient dispersion of ceria crystallites on $\mathrm{ZnO}$ [111,112] with higher surface area, presenting more and more active sites for the redox reactions. Magesh et al. [113] found that redshift is observed for $\mathrm{TiO}_{2}$ modified with Ce compared to $\mathrm{TiO}_{2}$ in UV-vis spectrophotometry and optimal Ce loading at $0.5-2.0 \%$ in the mixed oxide $\mathrm{CeO}_{2}-\mathrm{TiO}_{2}$ proved active under visible light for the $\mathrm{MB}$ photocatalytic decomposition. Photocatalytic activity of $\mathrm{CuO} / \mathrm{CeO}_{2}$ was also explored and reported to exhibit high performance owing to redox behavior of $\mathrm{CeO}_{2}$ and its strong interaction between $\mathrm{CuO}$ and $\mathrm{CeO}_{2}$ [114]. Irradiation by different light on the photocatalyst tailors the photodriven catalytic performance. Tung et al. have reported that under UV light irradiation, iron-doped $\mathrm{TiO}_{2}$ reveal consideration increment in photoactivity than that of pure $\mathrm{TiO}_{2}$ or Iron oxide [115]. This enhancement may be ascribed to impedance of electron/hole recombination with the incorporation of Fe ion in $\mathrm{TiO}_{2}$ lattice. On the other hand, photoactive performance of the catalyst transforms under visible light state. It illustrates that pure iron (II, III) oxide exhibits excellent photoactive behavior which surpasses that of $\mathrm{TiO}_{2}$. Iron doping at $0.5 \mathrm{~mol}$ in $\mathrm{TiO}_{2}$ made it comparable and for $1 \mathrm{~mol}$, no increment was observed. Hence, iron-doped $\mathrm{TiO}_{2}$ (photocatalyst) reacted differently under UV and visible light with no adverse effect on photoactivity in the former 
case. The formation of recombination sites was observed via iron doping in $\mathrm{TiO}_{2}$ under visible light, thereby reducing photodriven catalysis. Zhu et al. also supported the above finding suggesting that the rate of recombination was decreased by utilizing iron ions as hole or electron snare in $\mathrm{TiO}_{2}$ [116]. Photocatalytic studies of $\mathrm{MnO}_{2} / \mathrm{Fe}_{3} \mathrm{O}_{4}$ nanocomposite show high photocatalytic efficiency and high stability with recyclability towards the degradation of MB under UV-vis illumination [117].

Different strategies have been reported to enhance the photocatalytic efficiency or retard the electron/hole recombination rate in mixed oxides. $\mathrm{TiO}_{2}-\mathrm{NiO}$ mixed oxide developed by sol gel method reportedly have high efficiency for photodriven MO removal [118]. This enhancement is attributed to the induced n-p junction at the interface, which prevents electron/hole recombination upon irradiation by light. This can be explained by (Figure 5) considering the existence of both $\mathrm{TiO}_{2}$ (n-type, electron rich) and $\mathrm{NiO}$ (p-type, hole rich) phases or n-p junction at the interfacial contact where diffusion of electrons and holes takes place to p-type and n-type semiconductors, respectively. At equilibrium, the internal electric field arises due to accumulation of electrons and holes, which act as potential barrier and prevent electron/hole recombination. They also investigated the variation of nickel content on catalytic efficiency of the synthesized composite. Highest efficiency was exhibited by $\mathrm{Ti}_{75}-\mathrm{Ni}_{25}$ composite, and with further increment in Ni content, specific surface area and total pore volume of the resulting composite diminishes, which is detrimental for photocatalytic reactions.

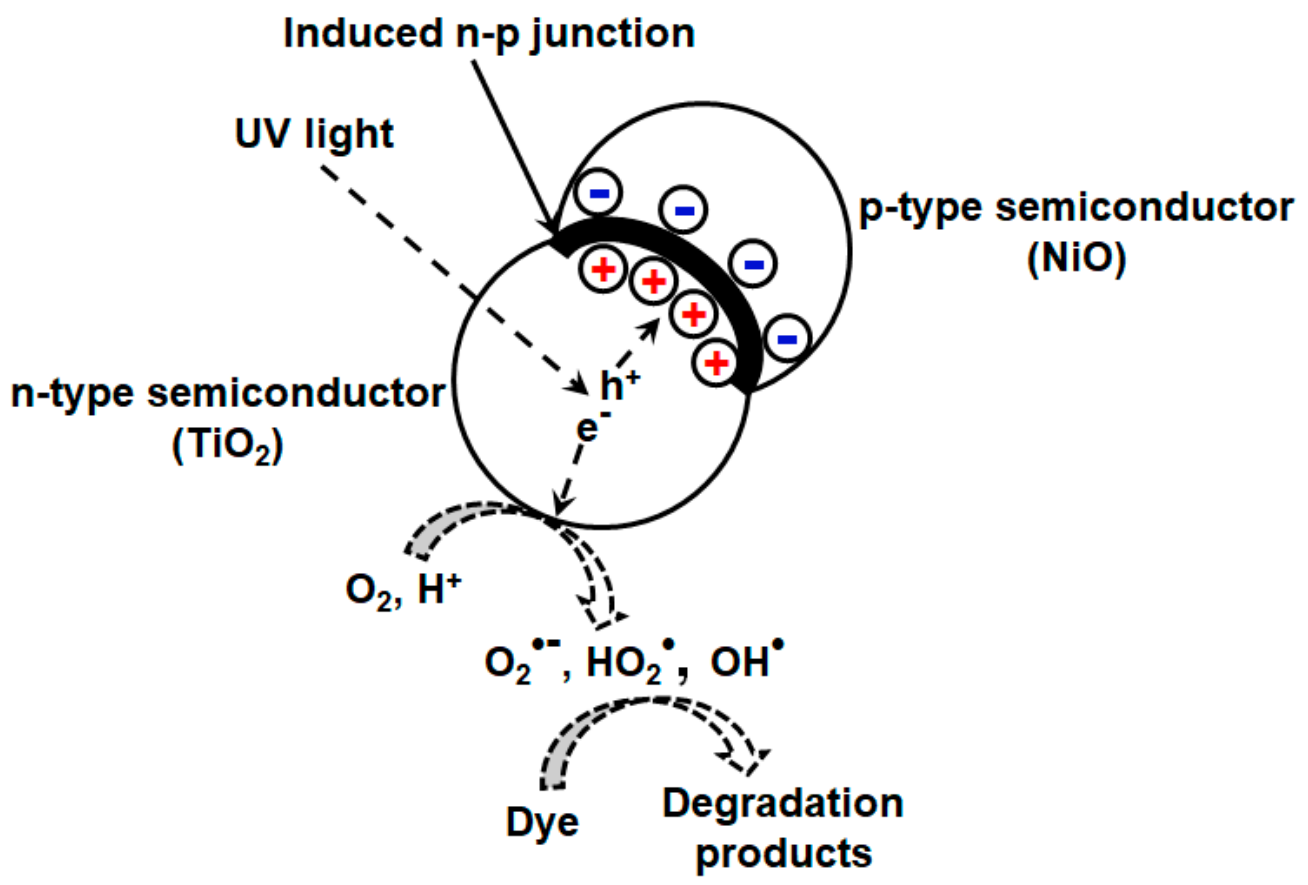

Figure 5. Schematic showing p-n junction at the interface of p-type $\mathrm{NiO}$ and n-type $\mathrm{TiO}_{2}$ semiconductors for improved photocatalytic degradation of $\mathrm{MO}$.

Sreethawong et al. loaded noble metal on the mixed oxides to enhance their photocatalytic rate [119]. Mesoporous assembled $\mathrm{TiO}_{2}-\mathrm{SiO}_{2}$ mixed oxides loaded with monometallic $\mathrm{Pt}$ and bimetallic $\mathrm{Pt}-\mathrm{Au}$ were studied as adsorbents under visible light driven catalysis for different loadings of $\mathrm{Au}$ and Pt. Similarly, Fe was introduced to $\mathrm{ZnO} / \mathrm{SiO}_{2}$ to improve their catalytic performance by shifting the absorption bandgap threshold from UV towards visible region, thereby modifying surface physical and chemical properties [120]. Various other factors say dye solution $\mathrm{pH}$, initial dye concentration, illumination time, and catalyst loading effecting photo-mediated oxidation of MB were investigated and explored for the photocatalytic process's optimal conditions. The efficiency of photocatalysis decreases with increase in $\mathrm{pH}$ with a value of $\sim 99.9 \%$ when $\mathrm{pH}$ increases from 2 to 4 . However, 
for negatively charged $\mathrm{MB}$ in acidic medium and positively charged $\mathrm{ZnO}$ below $\mathrm{pH} 9$, increase in $\mathrm{pH}$ change the charge on $\mathrm{ZnO}$ by absorbing $\mathrm{OH}^{-}$ions favoring the formation of ${ }^{\bullet} \mathrm{OH}$ radicals resulting in diminished photoactive efficiency. This is due to gradual increase in electrostatic repulsion between anionic dye and $\mathrm{ZnO}$. Additionally, catalyst loading also has considerable effect on photoactivity of $\mathrm{Fe} / \mathrm{ZnO}-\mathrm{SiO}_{2}$. When loading increased above $0.1 \mathrm{~g}$, efficiency decreases owing to agglomeration of catalyst particles as a consequence of increase in particle size and decrease in surface area, diminishing the number of surface-active sites. Further, the effect of different loading of $\mathrm{MnO}_{2}$ over $\mathrm{TiO}_{2}$ is explored by Xue et al. and reported to have high surface area and large pore size with enhanced adsorption properties over whole region of visible light [121]. The enlargement of the pore size is explored and attributed to the coating mechanism where dopant $\mathrm{Mn}^{+2}$ is coated onto the host in the synthesis procedure. During the synthesis, the formation of $\mathrm{TiO}_{2}$ nanoclusters takes place with the oxidation of $\mathrm{Mn}^{+2}$ to $\mathrm{MnO}_{2}$ in air which resist $\mathrm{TiO}_{2}$ nanoclusters to join together. The clusters were thus prevented to come close to form a small pore, subsequently affected the crystallization of $\mathrm{TiO}_{2}$. This led to remarkable absorption of visible light due to narrow band gap of $\mathrm{MnO}_{2}$. Wang et al. reported a $\mathrm{SnO}_{2}-$ $\mathrm{TiO}_{2}$ photocatalyst based on $\mathrm{TiO}_{2}$ nanofibers by electrospinning followed by hydrothermal treatment [122]. Under UV light illumination, $\mathrm{SnO}_{2}-\mathrm{TiO}_{2}$ composite exhibits almost 2.5 times higher than $\mathrm{TiO}_{2}$ photoactivity for $\mathrm{RB}$ mineralization. Li et al. synthesized $\mathrm{MnO}_{2}$ loaded $\mathrm{CuO}$ nanosheets and reported to possess high catalytic activity due to its composite phases, large surface area and dispersibility [123]. Series of $\mathrm{CuO} / \mathrm{MnO}_{2}$ compounds with different $\mathrm{CuO}$ loadings was synthesized and demonstrate the highly efficient $\mathrm{CuO} / \mathrm{MnO}_{2}$ interfaces as active sites for photocatalysis [124]. $\mathrm{MnO}_{2}$ layer is also coated on $\mathrm{CuO}$ to form nanorod array which addresses the issues related with the powder catalysis say easy agglomeration, difficult separation and possible secondary pollution [125]. In spite of this, metal vanadates are also widely utilized for photocatalysis. Recently, bismuth vanadate, $\mathrm{BiVO}_{4}$ with layered structure and bandgap $2.4 \mathrm{eV}$ was reported with varying molar ratio of $\mathrm{Bi}$ to $\mathrm{V}$ [126]. By alteration in the molar ratio, different crystal structures were obtained, tetragonal scheelite (ts), monoclinic scheelite (ms) and tetragonal zircon (tz). Amongst them, a higher photocatalytic activity under UV light has been exhibited by $\mathrm{ms}-\mathrm{BiVO}_{4}$, despite the consequences of its morphology with different dyes say RB and MB. Moreover, it demonstrates the potential of $\mathrm{ms}^{-} \mathrm{BiVO}_{4}$ under $6 \mathrm{~h}$ visible light illumination with degradation efficiency of $65.0 \%$ for MB and $77.8 \%$ for RB. Shang et al. [127] also reported nanosized $\mathrm{BiVO}_{4}($ dia $60 \mathrm{~nm})$ with visible light-driven photocatalytic activity. They suggested that nano $\mathrm{BiVO}_{4}$ possessed excellent photocatalytic efficiency towards the degradation of RB in 40 min. Furthermore, Yin et al. [128] synthesized ms- $\mathrm{BiVO}_{4}$ by using cetyltrimethylammonium bromide (CTAB) and reported that CTAB transformed the mechanism of reaction with the formation of an intermediate $\mathrm{BiOBr}$. Besides high photocatalytic efficiency, no considerable loss was witnessed after five cycles, signifying the high stability and absence of photocorrosion during RB degradation by $\mathrm{ms}-\mathrm{BiVO}_{4}$.

Despite metal vanadates, different metal molybdenum oxides were reported as efficient photocatalysts for the treatment of wastewater using UV or visible light illumination [129-131]. Xu et al. demonstrated high photocatalytic degradation activity of $90 \%$ under visible light irradiation for $\mathrm{MO}$ treatment using zeolite supported $\mathrm{Bi}_{2} \mathrm{MoO}_{6}$ [131]. This enhanced performance is attributed to uniform distribution of $\mathrm{Bi}_{2} \mathrm{MoO}_{6}$ nanoparticles on zeolite. $\mathrm{ZrMo}_{2} \mathrm{O}_{8}$ was reported by solid state technique and possess $\mathrm{ZrO}_{8}$ and $\mathrm{Mo}_{2} \mathrm{O}_{8}$ polyhedra [132]. It has specific degradation properties towards cationic dyes, say malachite green (MG) and RB.

Various other bimetallic oxides such as $\mathrm{NaTaO}_{3}, \mathrm{CoTaO}_{6}$ and $\mathrm{CeTaO}_{4}$ were supposed to have extended conduction and valence band, increasing the lifetime of photogeneration transporters, promoting the redox reaction on the catalyst surface [133-136]. Application of Fe-Co mixed oxide with varying Fe/Co ratio for degradation of 2, 4-dichlorophenol was explored and proved effective than bulk $\mathrm{Co}_{3} \mathrm{O}_{4}$ [137]. Authors also examined $\mathrm{Co}_{\mathrm{x}} \mathrm{Fe}_{3-\mathrm{x}} \mathrm{O}_{4}$ nanoparticles for $\mathrm{RB}$ heterogeneous degradation and revealed that higher cobalt content 
results inefficient removal of the dye. Another bimetallic oxide $\mathrm{NaBiO}_{3}$ examined under visible light irradiation for RB degradation via direct cleavage of the conjugated chromophore of dye molecule along with the degradation as dominating mechanism [138].

Besides this positive effect of bimetallic oxide interaction, the photocatalytic efficiency can also be poisoned via metal-metal ion interaction. Influence of different crystallographic forms of $\mathrm{MnO}_{2}$ on Degussa P-25 $\mathrm{TiO}_{2}$ resulted in photocatalytic inhibition or complete deactivation depending upon the amount of $\mathrm{MnO}_{2}$ [139]. This is due to the heterojunction formation at $\mathrm{MnO}_{2}-\mathrm{TiO}_{2}$ interface which alter the chemical state of $\mathrm{Ti}^{+4}$ and $\mathrm{O}^{-2}$ sites in $\mathrm{TiO}_{2}$. $\mathrm{MnO}_{2}$ also widen the bandgap of $\mathrm{TiO}_{2}$, thereby diminishing the UV absorption by creating impurity energy levels which serve as a recombination center for photoexcited charged carriers.

Among various mixed oxides formed via doping of foreign transition metal ion in host transition metal oxides, spinel oxides form a special class which have narrower bandgap with efficient catalytic properties. Spinel oxides synthesized by different methods possess high electrochemical activity with facilitated charge transfer [140-145]. Nano iron-cobalt spinel oxide was explored for photocatalytic activity via mineralization of monoazo-dye Acid Orange 7 with sulfate radicals in aqueous solution [146]. Quenching studies established that sulfate radicals are the primary species produced in the dye's catalytic degradation, which enhances the efficiency of the photocatalyst. Further, 3D magnetic $\mathrm{ZnFe}_{2} \mathrm{O}_{4} / \mathrm{MnO}_{2}$ hybrid was explored for photocatalysis and found to possess better activity (owing to its high BET surface area) with easy recyclability from reaction solution [147]. Cobalt ferrite, $\mathrm{CoFe}_{2} \mathrm{O}_{4}$ was synthesized by co-precipitation on the $\mathrm{TiO}_{2}$ surface to achieve recyclability with efficient photocatalytic ability which is estimated by following the degradation kinetics of textile dye in absence and presence of different electron acceptors [148]. It displayed maximum increase in the decomposition of Reactive red 120 (dye) in peroxomonosulphate (PMS) as compared to other electron acceptors. Ordinary $\mathrm{NiCo}_{2} \mathrm{O}_{4}$ and their core ring structured nanoplatelets were developed by Cui et al., which reports that the core ring $\mathrm{NiCo}_{2} \mathrm{O}_{4}$ nanoplatelets display elevated photocatalytic activity $\mathrm{MB}$ demineralization under visible light [149]. This enhanced property is attributed to smaller size, high absorption capacity with active and efficient internal electronic transitions. In addition, the core ring structure provides larger surface area and active surface Co atoms which could be the primary reason for outstanding photoactivity. Various other composites of doped transition metal oxides or bimetallic oxides with improved photocatalytic activity are included in Table 1 [132,150-161].

\subsection{Carbon Based Composites as Photocatalyst}

Another approach is to enhance the adsorption capacity with larger electron/hole recombination lifetime. This can be achieved by supporting the transition metal oxides over coadsorbent (support) which should have high adsorption capacity. The co-adsorbent should have high surface area and network conductivity for efficient adsorption and facilitated charge transfer processes, respectively. Carbonaceous materials such as activated carbons, carbon nanotubes and graphene are interesting and potential material for co-adsorbents owing to their higher surface area, unique pore structure and high conductivity [162-168]. Predominantly, the functions of co-adsorbent or support are as follows:

i. Reduce agglomeration of the particles

ii. Enhance surface area of the resulting composite

iii. Govern the life span of the photocatalyst via reducing the recombination rate of charged carriers

Activated carbon- $\mathrm{TiO}_{2}$ composites have been reported to exhibit improvement in photocatalytic activity attributed to the high adsorption capacity of the support and ready passage of charged carriers to $\mathrm{TiO}_{2}$ particles [169-173]. However, under-exploitation of nanotexture and nanoscale phenomena with untackled bandgap engineering needs researchers to explore other alternatives $[174,175]$. Carbon nanotubes (CNTs) are reported to possess effective synergism with $\mathrm{TiO}_{2}$ to enhance photocatalysis by diminishing the electron/hole 
recombination [176-178]. Hoffmann et al. reported $\mathrm{TiO}_{2}-\mathrm{CNT}$ composite with transference of photogenerated electrons to CNTs and holes to $\mathrm{TiO}_{2}$, thus impeding the reblending of electrons and holes [179]. MWCNT $\mathrm{TiO}_{2}$ composites have been extensively reported to improve their photocatalytic activity $[180,181]$. Magnetic photocatalyst, $\mathrm{NiFe}_{2} \mathrm{O}_{4} / \mathrm{MWNT}$ was synthesized by hydrothermal method and exhibited high photoactivity [182]. The poorly active $\mathrm{NiFe}_{2} \mathrm{O}_{4}$ nanocrystals are significantly converted into active one in the presence of MWNT, and this is attributed to synergism between the two with effective charge transfer and declined rate of recombination of photogenerated carriers. In addition to this, their remarkable magnetic property made it efficiently recyclable using an external magnet.

Table 1. Photocatalytic performance of bimetallic transition metal oxides. N.A. = data not available.

\begin{tabular}{|c|c|c|c|c|}
\hline Photocatalyst & Synthetic Method & Performance & Reusability & Reference \\
\hline $\begin{array}{l}\mathrm{ZnO} \text { microflower on } \\
\text { Stainless steel (SS) }\end{array}$ & $\begin{array}{l}\text { Spray pyrolysis of zinc acetate } \\
\text { on SS }\end{array}$ & $\begin{array}{l}\text { Decolorization efficiency (DE) } \\
96 \% \text { in } 120 \text { min under Sunlight }\end{array}$ & $\begin{array}{l}98 \% \text { efficiency } \\
\text { after } 4 \text { cycles }\end{array}$ & [150] \\
\hline $\mathrm{Mn}-\mathrm{ZnO}$ & $\begin{array}{c}\text { Grinding } \mathrm{Zn}\left(\mathrm{NO}_{3}\right)_{2} \cdot 6 \mathrm{H}_{2} \mathrm{O} \text { and } \\
\mathrm{Mn}\left(\mathrm{CH}_{3} \mathrm{CO}_{2}\right)_{2} \cdot 4 \mathrm{H}_{2} \mathrm{O} \text { using } \\
\mathrm{NaOH} \text { oxidant and SDS capping }\end{array}$ & $\begin{array}{l}\mathrm{DE} 99 \% \text { in } 20 \text { min under } \\
\text { visible light }\end{array}$ & $\begin{array}{l}96 \% \text { efficiency } \\
\text { after } 4 \text { cycles }\end{array}$ & [151] \\
\hline $\mathrm{WO}_{3} / \mathrm{SiO}_{2}$ & $\begin{array}{l}\text { Impregnation followed by } \\
\text { calcination Sodium Tungstate } \\
\text { Dihydrate on } \mathrm{SiO}_{2} \text { monoliths }\end{array}$ & $\begin{array}{l}\text { DE } 96 \% \text { in } 120 \text { min under } \\
\text { visible light }\end{array}$ & $\begin{array}{l}80 \% \text { efficiency } \\
\text { after } 5 \text { cycles }\end{array}$ & [152] \\
\hline $\mathrm{ZnO}-\mathrm{TiO}_{2}$ & $\begin{array}{c}\text { Sol gel synthesis using } \mathrm{TiCl}_{4} \text { and } \\
\mathrm{Zn}\left(\mathrm{CH}_{3} \mathrm{COO}\right)_{2} \text { with calcinations } \\
\text { at }\left(160-900^{\circ} \mathrm{C}\right)\end{array}$ & $\begin{array}{l}\text { DE } 100 \% \text { in } 10 \text { min under } \\
\text { UV irradiation }\end{array}$ & N.A. & [153] \\
\hline $\mathrm{WO}_{x}-\mathrm{TiO}_{2}$ & $\begin{array}{l}\text { Sol gel synthesis with thermal } \\
\text { activation in vacuum }\end{array}$ & $\begin{array}{l}\text { DE } 100 \% \text { under visible } \\
\text { irradiation in } 240 \text { min of } \\
\text { irradiation time }\end{array}$ & $\begin{array}{l}90 \% \text { efficiency } \\
\text { after } 5 \text { cycles }\end{array}$ & [154] \\
\hline $\begin{array}{l}\mathrm{Fe}, \mathrm{Co}, \mathrm{Ni}, \mathrm{Cu}, \\
\quad \mathrm{Zn}-\mathrm{TiO}_{2}\end{array}$ & $\begin{array}{l}\text { Sol gel method modified with } \\
\text { ionic liquid }\end{array}$ & $\begin{array}{c}\mathrm{DE} 90 \% \mathrm{Fe}-\mathrm{TiO}_{2} 80 \% \mathrm{Co}-\mathrm{TiO}_{2} \\
12 \% \mathrm{Ni}-\mathrm{TiO}_{2} \\
8 \% \mathrm{Zn}-\mathrm{TiO}_{2} \\
20 \% \mathrm{Cu}-\mathrm{TiO}_{2} \\
\text { Under UV irradiation of } 120 \mathrm{~min}\end{array}$ & N.A. & [155] \\
\hline $\mathrm{ZnO}-\mathrm{SnO}$ & $\mathrm{ZnO}$ by impregnation on silica & $\begin{array}{l}\text { DE } 90 \% \text { under UV irradiation for } \\
60 \mathrm{~min}\end{array}$ & N.A. & [156] \\
\hline $\mathrm{Mn}^{+2}-\mathrm{ZnO}$ & $\begin{array}{l}\text { Co-precipitation of zinc acetate } \\
\text { with manganese acetate dopant }\end{array}$ & $\begin{array}{l}\mathrm{DE} \sim 93.3 \% \text { under } \mathrm{UV} \\
\text { illumination for } 120 \mathrm{~min}\end{array}$ & N.A. & [157] \\
\hline $\mathrm{BiVO}_{4}$ & $\begin{array}{l}\text { Hydrothermal synthesis from } \\
\mathrm{Bi}\left(\mathrm{NO}_{3}\right)_{3} \cdot 5 \mathrm{H}_{2} \mathrm{O}+\mathrm{NH}_{4} \mathrm{VO}_{3}\end{array}$ & $\begin{array}{c}\mathrm{DE} 100 \% \mathrm{msBiVO}_{4} 92.9 \% \\
\text { tz-BiVO } \\
30.5 \% \text { ts-BiVO }\end{array}$ & N.A. & [126] \\
\hline $\mathrm{Bi}_{2} \mathrm{WO}_{6}$ & Hydrothermal method & $\begin{array}{l}\text { DE 97\% under visible light } \\
\text { irradiation of } 320 \mathrm{~min}\end{array}$ & N.A. & [158] \\
\hline $\mathrm{ZnWO}_{4}$ & $\begin{array}{l}\text { Template method involving } \\
\mathrm{H}_{2} \mathrm{WO}_{4} \text { and } \mathrm{Na}_{2} \mathrm{WO}_{4}\end{array}$ & $\begin{array}{l}\mathrm{DE}>95 \% \text { under UV irradiation } \\
\text { of } 40 \mathrm{~min}\end{array}$ & N.A. & [159] \\
\hline $\mathrm{ZnWO}_{3}$ & Impregnation method & $\begin{array}{l}\sim 90 \% \text { under laser irradiation for } \\
15 \mathrm{~min}\end{array}$ & N.A. & [160] \\
\hline$\beta-\mathrm{ZrMo}_{2} \mathrm{O}_{8}$ & Solid state synthesis & No data & N.A. & [132] \\
\hline $\mathrm{CeO}_{2}-\mathrm{TiO}_{2}$ & Polymer assisted method & $24 \%$ visible irradiation of $90 \mathrm{~min}$ & N.A. & [113] \\
\hline$\beta-\mathrm{SnWO}_{4}$ & Solid state reaction & $\begin{array}{l}90 \% \text { under visible irradiation of } \\
120 \mathrm{~min}\end{array}$ & N.A. & [161] \\
\hline
\end{tabular}

Among various carbonaceous material, graphene, two-dimensional sheets of $\mathrm{sp}^{2}$ hybridized carbon, possess high charge carrier mobility with excellent mechanical strength [183]. Graphene can tailor the particle size and microstructure of the guest material and pro- 
mote electron transfer in photocatalytic reactions [184]. Direct growth of transition metal salt on graphene oxide (GO) has been widely used for graphene/metal oxide composites [185]. In spite of this, various other graphene-based composites are in-situ synthesis and hydrothermal or solvothermal approach.

\subsubsection{In-Situ Synthesis}

During this, metal salts and graphene oxide (GO) are used as substrates. The salt is then added to GO (dispersed solution) followed by conversion to metal oxide in the oxidizing agent's presence, followed by the reduction of GO to graphene [141-143,167]. Graphene- $\mathrm{ZnO}$ composite was synthesized by adsorbing $\mathrm{Zn}^{+2}$ ions on graphene oxide sheets in the presence of $\mathrm{NaOH}$ and $\mathrm{NaBF}_{4}$ followed by drying at $150{ }^{\circ} \mathrm{C}$ [186]. Similarly, $\mathrm{SnO}_{2}$ and $\mathrm{TiO}_{2}$ were grown over graphene by taking $\mathrm{SnCl}_{2}$ and $\mathrm{TiCl}_{3}$ as substrates [187]. Different morphological structures were obtained by reducing Sn and Ti salts in presence of GO by the same method. This can be attributed to different hydrolysis rate of the salt with their reduction abilities. Researchers have utilized different methods for dispersing graphene oxide while synthesizing different graphene-based composites via in-situ method [188,189]. Anionic surfactants have also been used for stabilizing graphene in aqueous solution for in situ growth of $\mathrm{TiO}_{2}$ over graphene [190]. Whereas, Park et al. reported graphite $\mathrm{TiO}_{2}$ composite via exfoliation-reorganization of graphite oxide without using any chemical reagents in aqueous slurry [191].

\subsubsection{Hydrothermal Approach}

During hydrothermal growth, precursors (semiconductor oxide) are loaded on graphene oxide in a dispersed medium followed by a higher temperature reduction. $\mathrm{ZnFe}_{2} \mathrm{O}_{4}$ /graphene composite was synthesized by the same method with $\mathrm{Zn}\left(\mathrm{NO}_{3}\right)_{2} \cdot 6 \mathrm{H}_{2} \mathrm{O}$ and $\mathrm{Fe}\left(\mathrm{NO}_{3}\right)_{2} \cdot 9 \mathrm{H}_{2} \mathrm{O}$ as precursors [192]. During growth, metal salts are oxidized with a reduction of graphene oxide. In-situ hydrothermal growth was utilized for graphene- $\mathrm{BiWO}_{6}$ by Mukherji et al. in the presence of graphene oxide [193]. Shen et al. synthesized graphene $\mathrm{TiO}_{2}$ composite via hydrothermal growth with scalable methods by utilizing water and glucose (reducing agent) [194]. Graphene $\mathrm{TiO}_{2}$ composite was dispersed by controlling the hydrolysis via one-step solvothermal approach to achieve a uniformly dispersed metal oxide over graphene [37].

\subsubsection{Photocatalytic Activity}

Graphene $\mathrm{TiO}_{2}$ nanocomposite, obtained via chemical oxidation of graphene suggested "on demand" graphene-metal oxide mechanism [195]. Functionalized GO nanosheets have efficient binding sites for metal oxide particles $\left(\mathrm{TiO}_{2}, \mathrm{ZnO}_{2}\right)$ and remain in solution without aggregation [196]. After photo-irradiation, the electrons interact with GO nanosheets to remove various oxygen functionalities yielding reduced graphene oxide (RGO) $[197,198]$. Some electrons are used for reduction purpose, and others are stored in RGO. The graphene $\mathrm{TiO}_{2}$ can be recovered after solvent evaporation. Photocatalytic degradation of $\mathrm{MB}$ using $\mathrm{TiO}_{2}$ nanorods $\mathrm{GO}$ composite exhibits anticharge recombination mechanism [199]. Authors found that the electrons at GO react with adsorbed oxygen to form ${ }^{\bullet} \mathrm{OH}$ radicals reducing the recombination of charge carriers $\left(\mathrm{e}^{-} / \mathrm{h}^{+}\right)$. Further, graphene presence in the composite influences the morphology and particle size distribution in the composite and accordingly alters the photocatalytic performance. Zhou et al. showed the uniform dispersion of $\mathrm{TiO}_{2}$ nanoparticles on graphene sheets with narrow particle size distribution resulting in superior photocatalytic activity under simulated sunlight irradiation [200]. The electron/hole pairs are produced in $\mathrm{TiO}_{2}$ upon illumination with UV light and the photoexcited electrons transfer to graphene sheets, scavenged by dissolved oxygen and promote the electron/hole separation. Additionally, Du et al. demonstrated the improved photocatalysis by ordered macro-mesoporous $\mathrm{TiO}_{2}$-graphene composite towards decomposition of $\mathrm{MB}$ in water than bare mesoporous $\mathrm{TiO}_{2}$ film [188]. All the 
above results of graphene-based composites displayed that graphene can promote charge separation in the composites and consequently results in high photocatalytic activity.

Graphene- $\mathrm{ZnO}$ composite was reported by adsorbing $\mathrm{Zn}^{+2}$ ions on GO sheets followed by addition of $\mathrm{NaOH}$ and $\mathrm{NaBH}_{4}$ [186]. Various graphene composites (ZnOgraphene, $\mathrm{Co}_{3} \mathrm{O}_{4}$-graphene, $\mathrm{Mn}_{3} \mathrm{O}_{4}$-graphene, etc.) have been explored for their photocatalytic application to purify wastewater $[186,201,202]$. These composites showed high adsorption capacity and large charge separation facilitating overall performance. The significant role of graphene in the graphene $\mathrm{TiO}_{2}$ composite is demonstrated by Zhang et al. [203] during the degradation of $\mathrm{MB}$ in water (Figure 6). Role of graphene and $\mathrm{CNT}$ were further explored by making their nanocomposites $\mathrm{CuO} . \mathrm{ZnO} . \mathrm{Fe}_{2} \mathrm{O}_{3} / \mathrm{rGO}$ and $\mathrm{CuO} . \mathrm{ZnO} . \mathrm{Fe}_{2} \mathrm{O}_{3} / \mathrm{CNTs}$ by utilizing against $\mathrm{MB}$ dye [204]. The resulting nanocomposites engendered stress in their lattice, resulting in some defects. These consequently resulted in enhanced chemical reactivity with improved efficiency owing to the newly generated electronic state resulting from varied interactions such as metal-metal, metal-oxygen-metal.

(a)

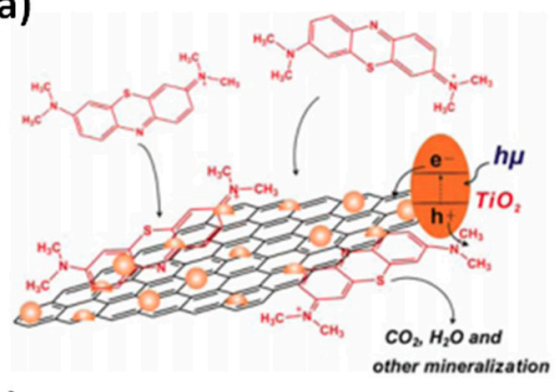

(c)

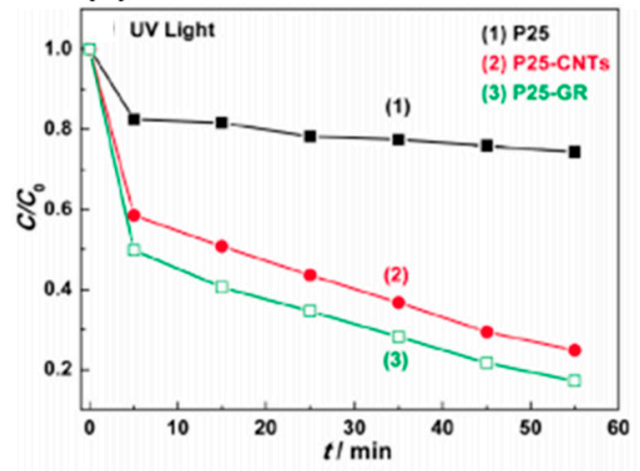

(b)

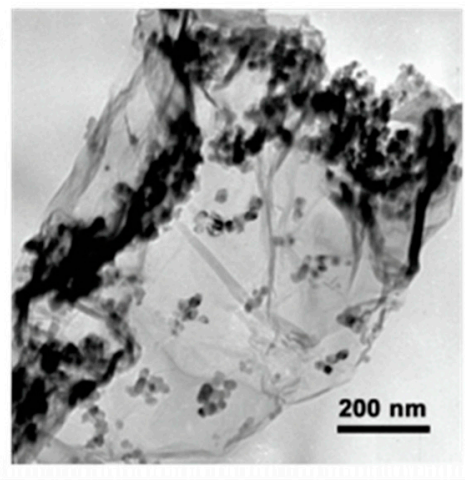

(d)

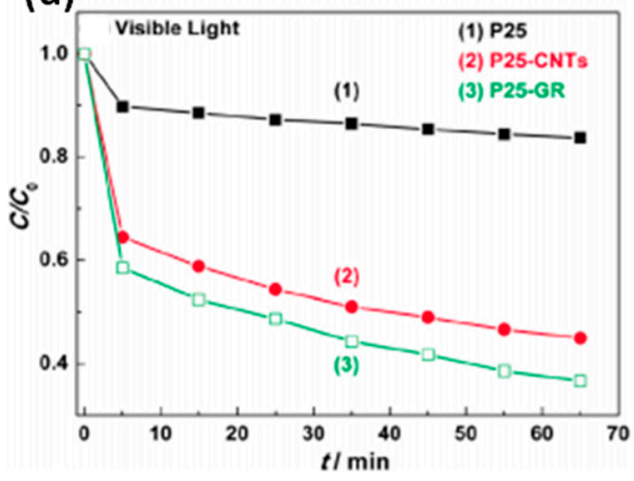

Figure 6. (a) Schematic of P25-GR and probable process of photodriven degradation of the dye (MB) over P-25-GR with TEM micrograph (b) of the composite. Comparison of photocatalytic activity in the degradation of MB under (c) UV light $(\lambda=365 \mathrm{~nm})$ and (d) visible light $(\lambda=400 \mathrm{~nm})$. Adapted with permission form Ref. [203]. Copyright 2010, American Chemical Society.

In addition, the graphene content in the composites significantly influences the photocatalytic efficiency. The effect of composites with different graphene content has been studied via photocatalytic degradation of $\mathrm{MB}$ in water [205]. Bai et al. utilized $\mathrm{Zn}_{1-\mathrm{x}} /$ graphene composite and provide insights for the development of graphene-based defect type material [206]. Superior photocatalytic activity of the synthesized composite corresponds to synergic effect of graphene and $\mathrm{Zn}_{1-\mathrm{x}}$ surface defect layer. The electron/hole separation results due to the elevation of highest occupied molecular orbital (HOMO) of graphene and $\mathrm{Oi}^{\prime \prime} \mathrm{ZnO}_{1-\mathrm{x}}$ defect level in $\mathrm{Zn}_{1-\mathrm{x}} /$ graphene composite (Figure 7). Non-stoichiometric $\mathrm{W}_{18} \mathrm{O}_{49}$ has been reported as a potential visible-driven photocatalyst due to its unusual defective structure [207]. 

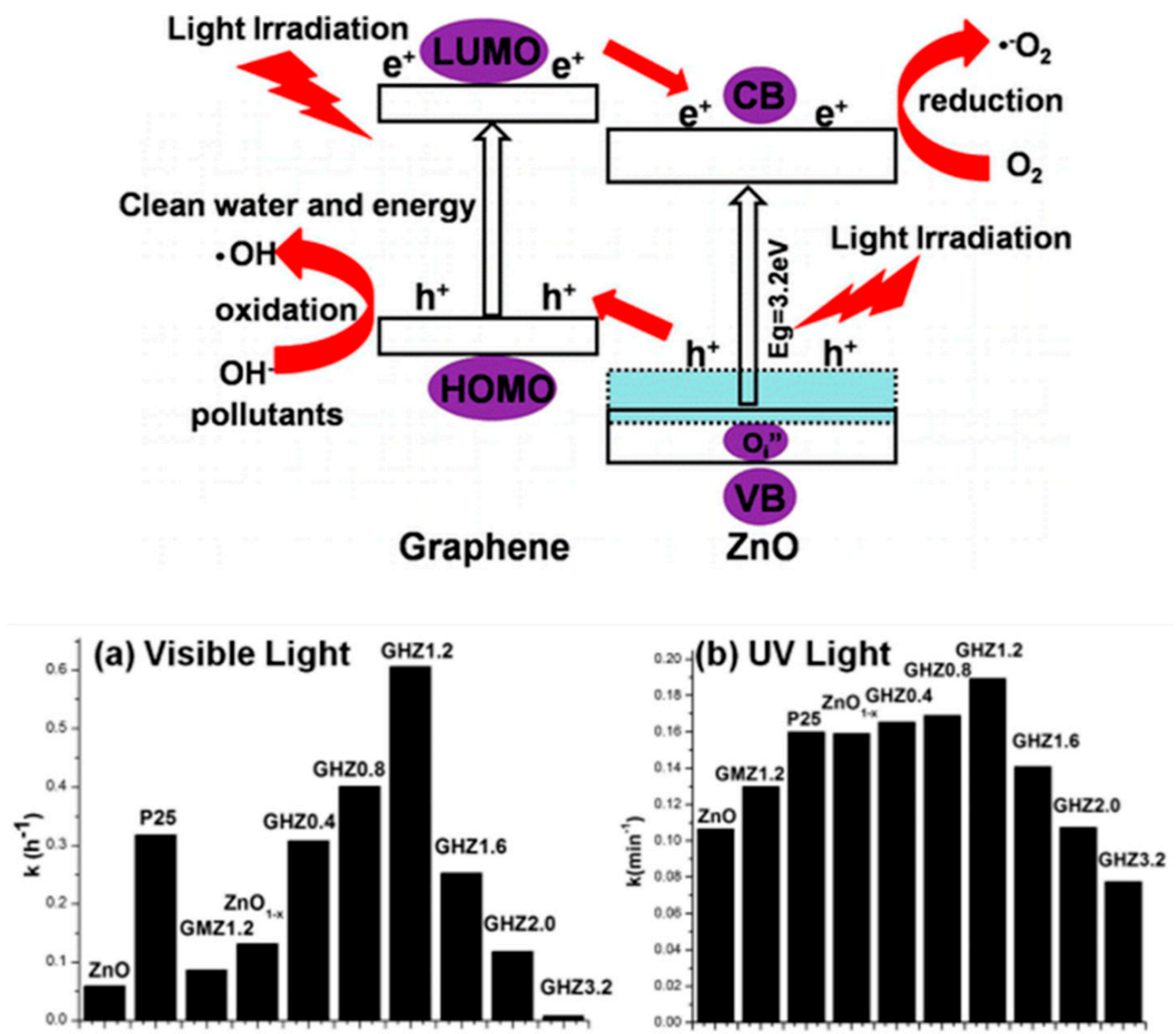

Figure 7. Schematic demonstrating the photocatalytic process over $\mathrm{ZnO}_{1-x} /$ graphene. Photocatalytic degradation of $\mathrm{MB}$ over $\mathrm{ZnO}_{1-\mathrm{x}}$ and $\mathrm{ZnO}_{1-\mathrm{x}}$ /graphene under illumination of (a) visible light and (b) UV light. Adapted with permission from [206]. Copyright 2013, American Chemical Society.

Du et al. further developed an approach to improve the charge carriers' diffusivity by employing hierarchical porous systems [188]. Macro-mesoporous titania graphene composite reduces the mesopore channel's diffusion length and enhances the effective surface area, resulting in diminished charge recombination rate. High photocatalytic efficiency of $\mathrm{MnO}_{2}$ graphene composite is attributed to synergism between graphene and $\mathrm{MnO}_{2}$ via efficient electron transfer channels with the high surface area for photoactive mineralization of MB [208]. Here, the adsorption-oxidation-desorption mechanism is involved for $\mathrm{MB}$ degradation. Firstly, $\mathrm{MnO}_{2}$ are adsorbed on graphene surface via $\pi-\pi$ conjugation, which effectively increases the $\mathrm{MB}$ concentration near the surface, enhancing the catalytic rate. Therefore, the coupling between adsorption and catalytic reaction for $\mathrm{MnO}_{2} / \mathrm{RGO}$ composite results in efficient decomposition of $\mathrm{MB}$ compared with bare components. $\mathrm{ZrO}_{2}$-graphene composites are also analyzed for photocatalysis and observed that degradation time decreases with enhanced degradation factor due to the inclusion of graphene in $\mathrm{ZrO}_{2}$ [209]. This is attributed to the immediate shifting of electrons to graphene followed by the generation of electrons and holes on irradiation. The conjugated $\left(\mathrm{sp}^{2}\right)$ carbon lattice increases light absorption range thereby promoting charge separation. In allusion to this, various other composites of graphene and transition metal oxides resulted with improved photocatalytic activity are presented in Table 2 [210-220]. 
Table 2. Photocatalytic properties of graphene-based composites (photocatalysts).

\begin{tabular}{|c|c|c|c|c|}
\hline $\begin{array}{l}\text { Composite } \\
\text { Photocatalyst }\end{array}$ & $\begin{array}{c}\text { Mass Fraction } \\
\text { of Graphene }\end{array}$ & Photocatalytic Activity & Reusability & References \\
\hline P25-G & $\begin{array}{c}5 \mathrm{wt} \% \\
10 \mathrm{wt} \% \\
20 \mathrm{wt} \% \\
30 \mathrm{wt} \%\end{array}$ & $\begin{array}{c}\mathrm{R}_{\mathrm{H} 2} 26 \mu \mathrm{mol} \mathrm{h}^{-1} \\
60 \mu \mathrm{mol} \mathrm{h}^{-1} \\
74 \mu \mathrm{mol} \mathrm{h}^{-1} \\
37 \mu \mathrm{mol} \mathrm{h}^{-1}\end{array}$ & N.A. & [183] \\
\hline $\mathrm{TiO}_{2}-\mathrm{G}$ & $6.5 \mathrm{wt} \%$ & $80 \mu \mathrm{mol}$ in $5 \mathrm{~h}$ & N.A. & [184] \\
\hline $\begin{array}{l}\mathrm{TiO}_{2}-\mathrm{G} \\
\mathrm{SnO}_{2}-\mathrm{G}\end{array}$ & $\begin{array}{l}15 \text { wt } \% \\
15 \text { wt } \%\end{array}$ & $\begin{array}{c}\text { Reaction rate } \\
0.0057 \mathrm{~min}^{-1} \\
0.011 \mathrm{~min}^{-1}\end{array}$ & N.A. & [187] \\
\hline $\mathrm{TiO}_{2}-\mathrm{G}$ & $0.6 \mathrm{wt} \%$ & Reaction rate $0.071 \mathrm{~min}^{-1}$ & N.A. & [188] \\
\hline $\mathrm{TiO}_{2}-\mathrm{GO}$ & $1 \mathrm{wt} \%$ & $175 \mathrm{~m} \mathrm{~mol}$ in $3 \mathrm{~h}$ & N.A. & [191] \\
\hline $\mathrm{ZnFe}_{2} \mathrm{O}_{4}-\mathrm{G}$ & $20 \mathrm{wt} \%$ & DP $99 \%$ & $\begin{array}{l}95 \% \text { efficiency } \\
\text { after } 10 \text { cycles }\end{array}$ & [192] \\
\hline $\mathrm{TiO}_{2}-\mathrm{G}$ & $25 \mathrm{wt} \%$ & $\mathrm{R}_{\mathrm{H} 2} 4 \mu \mathrm{mol} \mathrm{h}^{-1}$ & N.A. & [194] \\
\hline $\mathrm{TiO}_{2}-\mathrm{G}$ & $\begin{array}{l}10 \mathrm{mg} \\
30 \mathrm{mg} \\
50 \mathrm{mg}\end{array}$ & $\begin{array}{l}\text { DP 58\% } \\
\text { DP 75\% } \\
\text { DP 72\% }\end{array}$ & N.A. & [209] \\
\hline $\begin{array}{c}\mathrm{TiO}_{2}-\mathrm{G} \text { Mixed } \\
\text { phases }\end{array}$ & $5 w t \%$ GO & $\begin{array}{c}\text { Degradation Percentage } \\
\text { (DP) } 93 \%\end{array}$ & $\begin{array}{l}90 \% \text { efficiency } \\
\text { after } 5 \text { cycles }\end{array}$ & [210] \\
\hline $\mathrm{TiO}_{2}-\mathrm{GO}$ & $20 w t \%$ & DP $96.62 \%$ & $\begin{array}{l}80 \% \text { efficiency } \\
\text { after } 3 \text { cycles }\end{array}$ & [211] \\
\hline $\mathrm{TiO}_{2} / \mathrm{ZnO} / \mathrm{G}$ & $5 w t \%$ GO & DP $99.2 \%$ & $\begin{array}{c}>92 \% \\
\text { efficiency after } \\
5 \text { cycles }\end{array}$ & [212] \\
\hline $\mathrm{Fe}_{2} \mathrm{O}_{3} / \mathrm{TiO}_{2}-\mathrm{G}$ & $20 \mathrm{mg}$ & DP $100 \%$ & $\begin{array}{c}>90 \% \\
\text { efficiency after } \\
4 \text { cycles }\end{array}$ & [213] \\
\hline $\mathrm{TiO}_{2}-\mathrm{GO}$ & $\begin{array}{l}0.13 w t \% \\
0.14 w t \% \\
0.25 w t \% \\
0.51 w t \%\end{array}$ & $\begin{array}{l}\text { DP } 26 \% \\
\text { DP } 35 \% \\
\text { DP } 22 \% \\
\text { DP } 18 \%\end{array}$ & N.A. & [214] \\
\hline $\mathrm{ZnO}-\mathrm{G}$ & $\begin{array}{l}0.05 w t \% \\
0.5 w t \% \\
1.0 w t \% \\
2.0 w t \% \\
3.0 w t \% \\
5.0 w t \%\end{array}$ & $\begin{array}{c}\text { Reaction rate } 0.047 \mathrm{~min}^{-1} \\
0.056 \mathrm{~min}^{-1} \\
0.069 \mathrm{~min}^{-1} \\
0.098 \mathrm{~min}^{-1} \\
0.091 \mathrm{~min}^{-1} \\
0.072 \mathrm{~min}^{-1}\end{array}$ & $\begin{array}{l}\text { No change in } \\
\text { photocatalytic } \\
\text { activity after } \\
5 \text { cycles }\end{array}$ & [215] \\
\hline $\begin{array}{l}\mathrm{Ag} / \mathrm{AgCl} / \mathrm{GO} \\
\mathrm{Ag} / \mathrm{AgBr} / \mathrm{GO}\end{array}$ & $0.6 \mathrm{wt} \%$ & $\begin{array}{l}\text { DP } 71 \% \\
\text { DP } 85 \%\end{array}$ & $\begin{array}{l}\text { No significant } \\
\text { change in } \\
\text { photocatalytic } \\
\text { activity after } \\
5 \text { cycles }\end{array}$ & [216] \\
\hline $\mathrm{BiVO}_{4}-\mathrm{G}$ & No data & $\mathrm{R}_{\mathrm{H} 2} 0.75 \mu \mathrm{mol} \mathrm{h}^{-1}$ & N.A. & [217] \\
\hline $\mathrm{TiO}_{2}-\mathrm{G}$ & $\begin{array}{c}\text { wt } \% \\
\text { wt } \% \\
10 \text { wt } \%\end{array}$ & $\begin{array}{l}\mathrm{R}_{\mathrm{H} 2} 6.5 \mu \mathrm{mol} \mathrm{h}^{-1} \\
\mathrm{R}_{\mathrm{H} 2} 8.6 \mu \mathrm{mol} \mathrm{h}^{-1} \\
\mathrm{R}_{\mathrm{H} 2} 4.7 \mu \mathrm{mol} \mathrm{h}^{-1}\end{array}$ & N.A. & [218] \\
\hline $\mathrm{InNbO}_{4}-\mathrm{G}$ & N.A. & $\begin{array}{l}\text { Reaction rate } \\
0.0346 \mathrm{~min}^{-1}\end{array}$ & N.A. & [219] \\
\hline $\mathrm{MnFe}_{2} \mathrm{O}_{4}-\mathrm{GSC}$ & $100 \mathrm{mg}$ & DP $100 \%$ with $\mathrm{H}_{2} \mathrm{O}_{2}$ & $\begin{array}{c}99.97 \% \\
\text { efficiency after } \\
5 \text { cycles }\end{array}$ & [220] \\
\hline
\end{tabular}


Besides graphene-based composites of mono transition metal oxides, their bimetallic composites have also been extensively explored with the benefits of visible light driven photocatalysis. As the major portion of solar energy falls under visible light, it also improves the composite's efficiency [221]. Enhanced diffusion coefficient associated with graphene-based spinel oxides composite may prove beneficial for photocatalysis application [141,143]. Fu and Wang et al. reported visible light-driven MB degradation by $\mathrm{ZnFe}_{2} \mathrm{O}_{4}$ graphene composite [192]. Here, the magnetic property of $\mathrm{ZnFe}_{2} \mathrm{O}_{4}$ makes the composite magnetically discrete from the suspension system negating the requirement of additional magnetic components. Visible light irradiation of $\mathrm{ZnFe}_{2} \mathrm{O}_{4}$ graphene composite results in effective charge separation and generates strong oxidants via photoactive degradation of $\mathrm{H}_{2} \mathrm{O}_{2}$ with enhanced stability. Enhanced charge transfer of the composite is also demonstrated by a small radius of the semicircle in high frequency region of impedance plot compared to that of bare $\mathrm{GO}$ and $\mathrm{ZnFe}_{2} \mathrm{O}_{4}$ (Figure 8). Further, $\mathrm{MnFe}_{2} \mathrm{O}_{4}-$ graphene sand composite was used as photocatalyst against $100 \% \mathrm{MB}$ degradation under sunlight irradiation [220]. The high performance resulted from simultaneous participation of $\mathrm{Mn}$ and $\mathrm{Fe}$ on the catalyst surface for the decomposing $\mathrm{H}_{2} \mathrm{O}_{2}$ and in the production of - $\mathrm{OH}$ favoring photogenerated carriers' separation in $\mathrm{MnFe}_{2} \mathrm{O}_{4}$. Hydrothermal growth of graphene- $\mathrm{BiWO}_{6}$, reported by Gao et al. [222], shows enhanced photocatalytic degradation activity under RB's visible light. The interaction of graphene with $\mathrm{BiWO}_{6}$ shifts the Fermi level and decrease the conduction band potential. Fu et al. reported the synergistic effect of $\mathrm{CuFe}_{2} \mathrm{O}_{4}$ nanoflakes and graphene sheets, resulting in superior photocatalytic performance. The possible mechanism of photocatalytic degradation takes place via the following steps:

$$
\begin{gathered}
\mathrm{CuFe}_{2} \mathrm{O}_{4}+\mathrm{h} v \rightarrow \mathrm{CuFe}_{2} \mathrm{O}_{4}\left(\mathrm{~h}^{+}+\mathrm{e}^{-}\right) \\
\mathrm{CuFe}_{2} \mathrm{O}_{4}\left(\mathrm{e}^{-}\right)+\text {graphene } \rightarrow \mathrm{CuFe}_{2} \mathrm{O}_{4}+\text { graphene }\left(\mathrm{e}^{-}\right) \\
\text {Graphene }\left(\mathrm{e}^{-}\right)+\mathrm{O}_{2} \rightarrow \mathrm{O}_{2}^{\bullet-}+\text { graphene } \\
\mathrm{CuFe}_{2} \mathrm{O}_{4}\left(\mathrm{~h}^{+}\right)+\mathrm{OH}^{-} \rightarrow \mathrm{CuFe}_{2} \mathrm{O}_{4}+{ }^{\bullet} \mathrm{OH} \\
\mathrm{CuFe}_{2} \mathrm{O}_{4}\left(\mathrm{~h}^{+}\right)+\mathrm{OH}+\mathrm{O}_{2}^{\bullet-}+\mathrm{MB} \rightarrow \mathrm{CO}_{2}+\mathrm{H}_{2} \mathrm{O}
\end{gathered}
$$

(a)

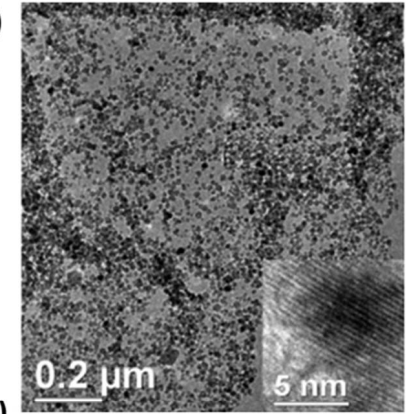

(c)

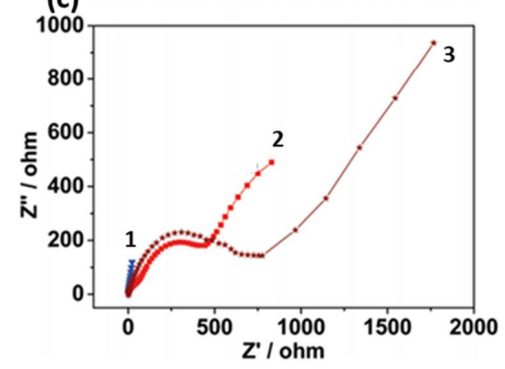

(b)

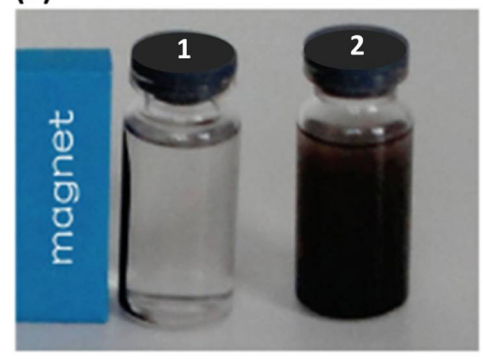

(d)

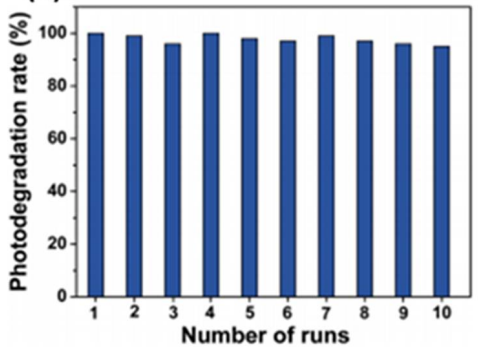

Figure 8. (a) Uniform dispersion of $\mathrm{ZnFe}_{2} \mathrm{O}_{4}$ nanoparticles over graphene (b) Images of $\mathrm{ZnFe}_{2} \mathrm{O}_{4}$ graphene suspension with (1) and without (2) magnetic field, (c) EIS of (1) ZnFe2O4 graphene, (2) pure $\mathrm{ZnFe}_{2} \mathrm{O}_{4}$ and (3) GO and (d) stability test shown by photodegradation rate of $\mathrm{MB}$ using $\mathrm{ZnFe}_{2} \mathrm{O}_{4}-\mathrm{G}$ for 10 cycles. Adapted with permission from [192]. Copyright 2011, American Chemical Society. 
Here, the generated active species oxidize MB molecules which are adsorbed on $\mathrm{CuFe}_{2} \mathrm{O}_{4}$ graphene composite via $\pi-\pi$ or electrostatic interaction. $\mathrm{CuBi}_{2} \mathrm{O}_{4} / \mathrm{G}$ was also evaluated for their photocatalytic performance after their synthesis by solvothermal method [223]. They possess $95 \%$ and $85 \%$ degradation efficiency towards degradation of $\mathrm{MB}$ and $\mathrm{MO}$ compared to pristine $\mathrm{CuBi}_{2} \mathrm{O}_{4}$. Visible light irradiation of $\mathrm{CuBi}_{2} \mathrm{O}_{4}$ result in the generation of electrons and holes on the surface followed by transference of photoexcited electrons to graphene sheets by percolation mechanism. Then, negatively charged graphene activates oxygen to form superoxide anion radicals and holes, which are adsorbed by water to produce hydroxyl radicals. Active species generated by graphene then oxidizes the dye molecule (adsorbed on the $\mathrm{CuBi}_{2} \mathrm{O}_{4}$-graphene active sites) and hence, increases the photocatalytic degradation rate of dyes from industrial effluents. These new adsorbents ensure visible light-driven dye degradation with large adsorption capacity and electron/hole recombination lifetime.

\section{Conclusions and Perspectives}

Photocatalysis is an imperative route for greener decipher of energy and environmental issues of modern era. Catalytic efficiency of various photocatalysts has been altered by employing different techniques by the researchers. This review has given stress over different adsorbents based on transition metal oxides, bimetallic oxides and their carbon composites for photocatalysis. Different approaches regarding synthetic technique, heterostructure, etc. led to augmented adsorptivity, light absorption intensity, electron/hole pair lifetime with extended light adsorption range which may unlock various breaks for the next generation photocatalysts. These approaches have been proved good but no one proved a panacea. However, the mechanistic description is still lacking and vigilant designs of the functional materials are vital for rational progress. It is worthy to note that although great improvements have been accomplished by utilizing the "rising star: graphene" in photocatalysis, still there are some challenges for full exploitation of graphene-based composites.

In addition to the above tactics to enhance photocatalysis, the deficiency in analogous results among various studies of photocatalysis led to a great challenge, in spite of a large amount of literature. Recently, the progress has been made on the utilization of nanocarbons for existing photocatalyst which improves the photocatalytic activity in a broad spectrum. Further, the photocatalysts' development and endorsement depend on the harmonic growth of academia and industrial revolution, particularly for the optimal testing condition and methods for dye degradation. The intensive efforts from systematic amalgamation of academician research worldwide would bring revolt in developing potential photocatalysts for dye degradation.

Author Contributions: P.A. (Preety Ahuja) and S.K.U.; writing original draft preparation, S.K.U., R.K. and P.A. (Pankaj Attri); review and editing. All authors have read and agreed to the published version of the manuscript.

Funding: Preety Ahuja acknowledges NPDF (project no. PDF/2015/000470) from the Department of Science and Technology, India; Pankaj Attri is thankful to JSPS-KAKENHI grant number 20K14454.

Conflicts of Interest: The authors declare no conflict of interest.

\section{References}

1. Wang, Y.; Sun, X.; Xian, T.; Liu, G.; Yang, H. Photocatlytic degradation of simulated dye wastewater in diferent $\mathrm{pH}$ environments by using $\mathrm{BaTiO}_{3} / \mathrm{Bi}_{2} \mathrm{WO}_{6}$ heterojunction photocatalysts. Opt. Mat. 2021, 113, 110853. [CrossRef]

2. Ning, L.; Xukai, L.; Mengting, H.; Xiaoguang, D.; Beibei, Y.; Guanyi, C.; Shaobin, W. Catalytic membrane-based oxidation-filtration systems for organic wastewater purification: A review. J. Hazard. Mater. 2021, 414, 125478.

3. Jaspal, D.; Malviya, A. Composites for wastewater purification: A review. Chemosphere 2020, 246, 125788. [CrossRef]

4. Chan, S.H.S.; Wu, T.Y.; Juan, J.C.; Teh, C.Y. Recent developments of metal oxide semiconductors as photocatalysts in advanced oxidation processes (AOPs) for treatment of dye wastewater. J. Chem. Technol. Biotechnol. 2011, 86, 1130-1158. [CrossRef]

5. Waters, B.D. The Regulator's View. In Colour in Dye House Effluent; Cooper, P., Ed.; The Society of Dyers and Colourists: Bradford, UK, 1995; pp. 22-30. 
6. Pereira, A.G.B.; Rodrigues, F.H.A.; Paulino, A.T.; Martins, A.F.; Fajardo, A.R. Recent advances on composite hydrogels designed for the remediation of dye-contaminated water and wastewater: A review. J. Clean. Prod. 2021, 284, 124703. [CrossRef]

7. Banat, I.M.; Nigam, P.; Singh, D.; Marchant, R. Microbial decolorization of textile-dye-containing effluents: A review. Bioresour. Technol. 1996, 58, 217-227. [CrossRef]

8. Schwarzenbach, R.P.; Escher, B.I.; Fenner, K.; Hofstettere, T.B.; Johnson, C.A.; Gunten, U.V.; Wehrli, B. The Challenge of Micropollutants in Aquatic Systems. Science 2006, 313, 1072-1077. [CrossRef] [PubMed]

9. Daneshvar, N.; Ashassi-Sorkhabi, H.; Tizpar, A. Decolorization of orange II by electrocoagulation method. Sep. Purif. Technol. 2003, 31, 153-162. [CrossRef]

10. Donkadokula, N.Y.; Kola, A.K.; Naz, I.; Saroj, D. A review on advanced physico-chemical and biological textile dye wastewater treatment techniques. Rev. Environ. Sci. BioTechnol. 2020, 19, 543-560. [CrossRef]

11. Kishor, R.; Purchase, D.; Saratale, G.D.; Saratale, R.G.; Ferreira, L.F.R.; Bilal, M.; Chandra, R.; Bhargava, R.N. Ecotoxicological and health concerns of persistent colouring pollutantsof textile industry wastewater and treatement approaches for environmental safety. J. Environ. Chem. Eng. 2021, 9, 105012. [CrossRef]

12. Kadirvelu, K.; Kavipriya, M.; Karthika, C.; Radhika, M.; Vennilamani, N.; Pattabhi, S. Utilization of various agricultural wastes for activated carbon preparation and application for the removal of dyes and metal ions from aqueous solutions. Bioresour. Technol. 2003, 87, 129-132. [CrossRef]

13. Baruah, S.; Dutta, J. Nanotechnology applications in pollution sensing and degradation in agriculture: A review. Environ. Chem. Lett. 2009, 7, 191-204. [CrossRef]

14. Choy, K.K.H.; McKay, G.; Porter, J.F. Resources, Sorption of acid dyes from effluents using activated carbon. Resour. Conserv. Recycl. 1999, 27, 57-71. [CrossRef]

15. Crini, G. Non-conventional low-cost adsorbents for dye removal: A review. Bioresour. Technol. 2006, 97, 1061-1085. [CrossRef]

16. Gupta, V.K.; Suhas. Application of low-cost adsorbents for dye removal-A review. J. Environ. Manag. 2009, 90, 2313-2342. [CrossRef]

17. Carvalho, M.C.; Pereira, C.; Gonçalves, I.C.; Pinheiro, H.M.; Santos, A.R.; Lopes, A.; Ferra, M.I. Assessment of the biodegradability of a monosulfonated azo dye and aromatic amines. Int. Biodeterior. Biodegrad. 2008, 62, 96-103. [CrossRef]

18. Lin, J.; Zhang, X.; Li, Z.; Lei, L. Biodegradation of Reactive blue 13 in a two-stage anaerobic/aerobic fluidized beds system with a Pseudomonas sp. isolate. Bioresour. Technol. 2010, 101, 34-40. [CrossRef] [PubMed]

19. Wafaa, M.A.E.-R.; Hassan, M.; Khalafallah, M. Microflora involved in textile dye waste removal. J. Basic Microbiol. 2003, 43, 167-174.

20. Ambrósio, S.T.; Campos-Takaki, G.M. Decolorization of reactive azo dyes by Cunninghamella elegans UCP 542 under co-metabolic conditions. Bioresour. Technol. 2004, 91, 69-75. [CrossRef]

21. Chander, M.; Arora, D.S. Evaluation of some white-rot fungi for their potential to decolourize industrial dyes. Dyes Pigm. 2007, 72, 192-198. [CrossRef]

22. Wesenberg, D.; Kyriakides, I.; Agathos, S.N. White-rot fungi and their enzymes for the treatment of industrial dye effluents. Biotechnol. Adv. 2003, 22, 161-187. [CrossRef]

23. Robinson, T.; McMullan, G.; Marchant, R.; Nigam, P. Remediation of dyes in textile effluent: A critical review on current treatment technologies with a proposed alternative. Bioresour. Technol. 2001, 77, 247-255. [CrossRef]

24. Lourenco, N.D.; Novais, J.M.; Pinheiro, H.M. Reactive textile dye colour removal in a sequencing batch reactor. Water Sci. Technol. 2000, 42, 321-328. [CrossRef]

25. Gürses, A.; Yalçina, M.; Dogar, C. Electrocoagulation of some reactive dyes: A statistical investigation of some electrochemical variables. Waste Manag. 2002, 22, 491-499. [CrossRef]

26. Hao, O.J.; Kim, H.; Chiang, P.C. Decolorization of Wastewater. Crit. Rev. Environ. Sci. Technol. 2000, 30, 449-505. [CrossRef]

27. Ullah, R.; Dutta, J. Photocatalytic degradation of organic dyes with manganese-doped ZnO nanoparticles. J. Hazard. Mater. 2008, 156, 194-200. [CrossRef] [PubMed]

28. Danish, M.S.S.; Estrella, L.L.; Alemaida, I.M.A.; Lisin, A.; Moiseev, N.; Ahmadi, M.; Nazari, M.; Wali, M.; Zaheb, H.; Senjyu, T. Photocatalytic Applications of Metal Oxides for Sustainable Environmental Remediation. Metals 2021, 11, 80. [CrossRef]

29. Gautam, S.; Agrawal, H.; Thakur, M.; Akbari, A.; Sharda, H.; Kaur, R.; Amini, M. Metal oxides and metal organic frameworks for the photocatalytic degradation: A review. J. Environ. Chem. Eng. 2020, 8, 103726. [CrossRef]

30. Zhu, J.; Jiang, Z. Electrochemical Photocatalytic Degradation of Eriochrome Black T Dye Using Synthesized TiO ${ }_{2} @ C_{N T s}$ Nanofibers. Int. J. Electrochem. Sci. 2021, 16, 210318. [CrossRef]

31. Sukri, S.N.A.M.; Shameli, K.; Isa, E.D.M.; Ismail, N.A. Green Synthesis of Zinc Oxide-Based Nanomaterials for Photocatalytic Studies: A Mini Review. IOP Conf. Ser. Mater. Sci. Eng. 2021, 1051, 012083. [CrossRef]

32. Thiruvenkatachari, R.; Vigneswaran, S.; Moon, I.S. A review on UV/ $\mathrm{TiO}_{2}$ photocatalytic oxidation process. Korean J. Chem. Eng. 2008, 25, 64-72. [CrossRef]

33. Ahmed, S.; Rasul, M.G.; Martens, W.N.; Brown, R.; Hashib, M.A. Advances in heterogeneous photocatalytic degradation of phenols and dyes in wastewater: A review. Water Air Soil Pollut. 2011, 215, 3-29. [CrossRef]

34. Malato, S.; Fernández-Ibáñez, P.; Maldonado, M.I.; Blanco, J.; Gernjak, W. Decontamination and disinfection of water by solar photocatalysis: Recent overview and trends. Catal. Today 2009, 147, 1-59. [CrossRef]

35. Woods-Robinson, R.; Han, Y.; Zhang, H.; Ablekim, T.; Khan, I.; Persson, K.A.; Zakutayev, A. Wide Band Gap Chalcogenide Semiconductors. Chem. Rev. 2020, 120, 4007-4055. [CrossRef] [PubMed] 
36. Gupta, S.M.; Tripathi, M. A review of $\mathrm{TiO}_{2}$ nanoparticles. Chi. Sci. Bull. 2011, 56, 1639-1657. [CrossRef]

37. Carp, O.; Huisman, C.L.; Reller, A. Photoinduced reactivity of titanium dioxide. Prog. Solid State Chem. $2004,32,33-177$. [CrossRef]

38. Sun, H.; Liu, S.; Liu, S.; Wang, S. A comparative study of reduced graphene oxide modified $\mathrm{TiO}_{2}, \mathrm{ZnO}_{\text {and }} \mathrm{Ta}_{2} \mathrm{O}_{5}$ in visible light photocatalytic/photochemical oxidation of methylene blue. Appl. Catal. B 2014, 146, 162-168. [CrossRef]

39. Haneda, D.L.H. Synthesis of nitrogen-containing $\mathrm{ZnO}$ powders by spray pyrolysis and their visible-light photocatalysis in gas-phase acetaldehyde decomposition. J. Photochem. Photobiol. A 2003, 155, 171-178.

40. Yang, G.C.C.; Chan, S.W. Photocatalytic reduction of chromium(VI) in aqueous solution using dye-sensitized nanoscale ZnO under visible light irradiation. J. Nanopart. Res. 2009, 11, 221-230. [CrossRef]

41. Huang, Y.; Wei, Y.; Wu, J.; Guo, C.; Wang, M.; Yin, S.; Sato, T. Low temperature synthesis and photocatalytic properties of highly oriented $\mathrm{ZnO} / \mathrm{TiO}_{2-\mathrm{x}} \mathrm{N}_{\mathrm{y}}$ coupled photocatalysts. Appl. Catal. B 2012, 123-124, 9-17. [CrossRef]

42. Maleh, H.K.; Kumar, B.G.; Rajendran, S.; Qin, J.; Vadivel, S.; Durgalakshmi, D.; Gracia, F.; Soto-Moscoso, M.; Orooji, Y.; Karimi, F. Tuning of metal oxides photocatalytic performance using Ag nanoparticles integration. J. Mol. Liq. 2020, 314, 113588. [CrossRef]

43. Karthikeyan, C.; Arunachalam, P.; Ramachandran, K.; Al-Mayouf, A.M.; Karuppuchamy, S. Recent advances in semiconductor metal oxides with enhanced methods for solar photocatalytic applications. J. Alloys Compd. 2020, 828, 154281. [CrossRef]

44. Oyewo, O.A.; Elemike, E.E.; Onwudiwe, D.C.; Onyango, M.S. Metal oxide-cellulose nanocomposites for the removal of toxic metals and dyes from wastewater. Int. J. Biol. Macromol. 2020, 164, 2477-2496. [CrossRef] [PubMed]

45. Fujishima, A.; Honda, K. Electrochemical Photolysis of Water at a Semiconductor Electrode. Nature 1972, 238, 37-38. [CrossRef]

46. Li, C.; Yuan, J.; Han, B.; Shangguan, W. Synthesis and photochemical performance of morphology-controlled CdS photocatalysts for hydrogen evolution under visible light. Int. J. Hydrogen Energy 2011, 36, 4271-4279. [CrossRef]

47. Fujita, E.; Muckerman, J.T.; Domen, K. Editorial: A current perspective on photocatalysis. Chemsuschem 2011, 4, 155-157. [CrossRef]

48. Hermann, J.M. Fundamentals and misconceptions in photocatalysis. J. Photochem. Photobio A 2010, 216, 85-93. [CrossRef]

49. Fujishima, A.; Zhang, X. Titanium dioxide photocatalysis: Present situation and future approaches. Comptes Rendus Chim. 2006, 9, 750-760. [CrossRef]

50. Zhao, D.; Chen, C.; Wang, Y.; Ma, W.; Zhao, J.; Rajh, T.; Zang, L. Enhanced photocatalytic degradation of dye pollutants under visible irradiation on $\mathrm{Al}(\mathrm{III})$-modified $\mathrm{TiO}_{2}$ : Structure, interaction, and interfacial electron transfer. Environ. Sci. Technol. 2008, 42, 308-314. [CrossRef]

51. Yu, J.; Xiong, J.; Cheng, B.; Liu, S. Fabrication and characterization of $\mathrm{Ag}-\mathrm{TiO}_{2}$ multiphase nanocomposite thin films with enhanced photocatalytic activity. Appl. Catal. B 2005, 60, 211-221. [CrossRef]

52. Sung-Suh, H.M.; Choi, J.R.; Hah, H.J.; Koo, S.M.; Bae, Y.C. Comparison of Ag deposition effects on the photocatalytic activity of nanoparticulate $\mathrm{TiO}_{2}$ under visible and UV light irradiation. J. Photochem. Photobiol. A 2004, 163, 37-44. [CrossRef]

53. Wilke, K.; Breuer, H.D. The influence of transition metal doping on the physical and photocatalytic properties of titania. J. Photochem. Photobiol. A 1999, 121, 49-53. [CrossRef]

54. Martin, S.T.; Morrison, C.L.; Hoffmann, M.R. Photochemical Mechanism of Size-Quantized Vanadium-Doped TiO 2 Particles. J. Phys. Chem. 1994, 98, 13695-13704. [CrossRef]

55. Choi, W.; Termin, A.; Hoffmann, M.R. The Role of Metal Ion Dopants in Quantum-Sized TiO 2 : Correlation between Photoreactivity and Charge Carrier Recombination Dynamics. J. Phys. Chem. 1994, 98, 13669-13679. [CrossRef]

56. Klosek, S.; Raftery, D. Visible Light Driven V-Doped $\mathrm{TiO}_{2}$ Photocatalyst and Its Photooxidation of Ethanol. J. Phys. Chem. B 2001, 105, 2815-2819. [CrossRef]

57. Sun, M.; Lin, T.; Cheng, G.; Ye, F.; Yu, L. Hydrothermal Synthesis of Boron-Doped $\mathrm{MnO}_{2}$ and Its Decolorization Performance. J. Nanomater. 2014, 2014, 175924. [CrossRef]

58. Ksibi, M.; Rossignol, S.; Tatibouët, J.-M.; Trapalis, C. Synthesis and solid characterization of nitrogen and sulfur-doped TiO 2 photocatalysts active under near visible light. Mater. Lett. 2008, 62, 4204-4206. [CrossRef]

59. Du, P.; Bueno-Lopez, A.; Verbaas, M.; Almeida, A.R.; Makkee, M.; Moulijin, J.A.; Mul, G. The effect of surface OH-population on the photocatalytic activity of rare earth-doped $\mathrm{P} 25-\mathrm{TiO}_{2}$ in methylene blue degradation. J. Catal. 2008, 260, 75-80. [CrossRef]

60. Zhu, J.; Xie, J.; Chen, M.; Jiang, D.; Wu, D. Low temperature synthesis of anatase rare earth doped titania-silica photocatalyst and its photocatalytic activity under solar-light. Colloids Surf. A Physicochem. Eng. Asp. 2010, 355, 178-182. [CrossRef]

61. Liu, R.; Wang, P.; Wang, X.; Yu, H.; Yu, J. UV- and Visible-Light Photocatalytic Activity of Simultaneously Deposited and Doped $\mathrm{Ag} / \mathrm{Ag}(\mathrm{I})-\mathrm{TiO}_{2}$ Photocatalyst. J. Phys. Chem. C 2012, 116, 17721-17728. [CrossRef]

62. Suda, Y.; Kawasaki, H.; Ueda, T.; Ohshima, T. Preparation of high quality nitrogen doped $\mathrm{TiO}_{2}$ thin film as a photocatalyst using a pulsed laser deposition method. Thin Solid Films 2004, 453-454, 162-166. [CrossRef]

63. Gole, J.L.; Stout, J.D.; Burda, C.; Lou, Y.; Chen, X. Highly Efficient Formation of Visible Light Tunable TiO ${ }_{2}-\mathrm{xNx}_{\mathrm{Nhotocatalysts}}$ and Their Transformation at the Nanoscale. J. Phys. Chem. B 2004, 108, 1230-1240. [CrossRef]

64. Miyauchi, M.; Ikezawa, A.; Tobimatsu, H.; Iriea, H.; Hashimoto, K. Zeta potential and photocatalytic activity of nitrogen doped $\mathrm{TiO}_{2}$ thin films. Phys. Chem. Chem. Phys. 2004, 6, 865-870. [CrossRef]

65. Hiromasa, T.; Masahiro, M. N-doped $\mathrm{TiO}_{2}$ Nanotube with Visible Light Activity. Chem. Lett. 2004, 33, $1108-1109$.

66. Wang, J.; Tafen, D.N.; Lewis, J.P.; Hong, Z.; Manivannan, A.; Zhi, M.; Li, M.; Wu, N. Origin of Photocatalytic Activity of Nitrogen-Doped $\mathrm{TiO}_{2}$ Nanobelts. J. Am. Chem. Soc. 2009, 131, 12290-12297. [CrossRef] 
67. Emeline, A.V.; Kuznetsov, V.N.; Rubchuk, V.K.; Serpone, N. Visible-Light-Active Titania Photocatalysts: The Case of N-Doped $\mathrm{TiO}_{2} \mathrm{~S}$-Properties and Some Fundamental Issues. Int. J. Photoenergy 2008, 2008, 258394. [CrossRef]

68. Wu, Z.; Dong, F.; Liu, Y.; Wang, H. Enhancement of the visible light photocatalytic performance of C-doped $\mathrm{TiO}_{2}$ by loading with $\mathrm{V}_{2} \mathrm{O}_{5}$. Catal. Commum. 2009, 11, 82-86. [CrossRef]

69. Daneshvar, N.; Salari, D.; Khataee, A.R. Photocatalytic degradation of azo dye acid red 14 in water on $\mathrm{ZnO}$ as an alternative catalyst to $\mathrm{TiO}_{2}$. J. Photochem. Photobiol. A 2004, 162, 317-322. [CrossRef]

70. Moussavi, G.; Mahmoudi, M. Removal of azo and anthraquinone reactive dyes from industrial wastewaters using $\mathrm{MgO}$ nanoparticles. J. Hazard. Mater. 2009, 168, 806-812. [CrossRef]

71. El-Hankari, S.; Aguilera-Sigalat, J.; Bradshaw, D. Surfactant-assisted ZnO processing as a versatile route to ZIF composites and hollow architectures with enhanced dye adsorption. J. Mater. Chem. A 2016, 4, 13509-13518. [CrossRef]

72. Kaliraj, L.; Ahn, J.C.; Rupa, E.J.; Abid, S.; Lu, J.; Yang, D.C. Synthesis of panos extract mediated ZnO nano-flowers as photocatalyst for industrial dye degradation by UV illumination. J. Photochem. Photobiol. B 2019, 199, 111588. [CrossRef]

73. Vinayagam, R.; Selvaraj, R.; Arivalagan, P.; Varadavenkatesan, T. Synthesis, characterization and photocatalytic dye degradation capability of Calliandra haematocephala-mediated zinc oxide nanoflowers. J. Photochem. Photobiol. B 2020, 203, 111760. [CrossRef]

74. Moghaddas, S.M.T.H.; Elahi, B.; Javanbakht, V. Biosynthesis of pure zinc oxide nanoparticles using Quince seed mucilage for photocatalytic dye degradation. J. Alloys Compd. 2020, 821, 153519. [CrossRef]

75. Kalpana, V.N.; Kataru, B.A.S.; Sravani, N.; Vigneshwari, T.; Panneerselvam, A.; Rajeswari, V.D. Biosynthesis of zinc oxide nanoparticles using culture filtrates of Aspergillus niger: Antimicrobial textiles and dye degradation studies. Open Nano 2018, 3, 48-55. [CrossRef]

76. Meng, A.; Xing, J.; Li, Z.; Li, Q. Cr-doped ZnO nanoparticles: Synthesis, characterization, adsorption property, and recyclability. ACS Appl. Mater. Interfaces 2015, 7, 27449-27457. [CrossRef] [PubMed]

77. Feng, W.; Nansheng, D.; Helin, H. Degradation mechanism of azo dye CI reactive red 2 by iron powder reduction and photooxidation in aqueous solutions. Chemosphere 2000, 41, 1233-1238. [CrossRef]

78. Khedr, M.H.; Abdel Halim, K.S.; Soliman, N.K. Synthesis and photocatalytic activity of nano-sized iron oxides. Mater. Lett. 2009, 63, 598-601. [CrossRef]

79. Kusior, A.; Michalec, K.; Jelen, P.; Radecka, M. Shaped $\mathrm{Fe}_{2} \mathrm{O}_{3}$ nanoparticles-Synthesis and enhanced photocatalytic degradation towards RhB. Appl. Surf. Sci. 2019, 476, 342-352. [CrossRef]

80. Shenoy, M.R.; Ayyasamy, S.; Reddy, M.V.V.; Kadarkarai, G.; Suryakanth, J.; Tamilarasan, S.; Thangavelu, S.; Jeyaramane, A.C. The effect of morphology-dependent surface charges of iron oxide on the visible light photocatalytic degradation of methylene blue dye. J. Mater. Sci. Mater. Electron. 2020, 31, 17703-17717. [CrossRef]

81. Kouhbanani, M.A.J.; Beheshtkhoo, N.; Taghizadeh, S.; Amani, A.M.; Alimardani, V. One-step green synthesis and characterization of iron oxide nanoparticles using aqueous leaf extract of Teucrium polium and their catalytic application in dye degradation. Adv. Nat. Sci. Nanosci. Nanotechnol. 2019, 10, 15007. [CrossRef]

82. Bishnoi, S.; Kumar, A.; Selvaraj, R. Facile synthesis of magnetic iron oxide nanoparticles using inedible Cynometra ramiflora fruit extract waste and their photocatalytic degradation of methylene blue dye. Mater. Res. Bull. 2018, 97, 121-127. [CrossRef]

83. Bibi, I.; Nazar, N.; Ata, S.; Sultan, M.; Ali, A.; Abbas, A.; Jilani, K.; Kamal, S.; Sarim, F.M.; Khan, M.I.; et al. Green synthesis of iron oxide nanoparticles using pomegranate seeds extract and photocatalytic activity evaluation for the degradation of textile dye. J. Mater. Res. Technol. 2019, 8, 6115-6124. [CrossRef]

84. Anchan, S.; Pai, S.; Sridevi, H.; Varadavenkatesan, T.; Vinayagam, R.; Selvaraj, R. Biogenic synthesis of ferric oxide nanoparticles using the leaf extract of Peltophorum pterocarpum and their catalytic dye degradation potential. Biocatal. Agric. Biotechnol. 2019, 20, 101251. [CrossRef]

85. Wang, C.-T. Photocatalytic activity of nanoparticle gold/iron oxide aerogels for azo dye degradation. J. Non-Cryst. Solids 2007, 353, 1126-1133. [CrossRef]

86. Mills, A.; Hunte, S.L. An overview of semiconductor photocatalysis. J. Photochem. Photobiol. A Chem. 1997, 108, 1-35. [CrossRef]

87. Guo, S.Y.; Han, S.; Chi, B.; Pu, J.; Li, J. A facile low-temperature approach to designing controlled amorphous-based titania composite photocatalysts with excellent noble-metal-free photocatalytic hydrogen production. ACS Appl. Mater. Interfaces 2014, 6, 4743-4751. [CrossRef] [PubMed]

88. Zhang, Y.X.; Guo, X.L.; Huang, M.; Hao, X.D.; Yuan, Y.; Hua, C. Engineering birnessite-type $\mathrm{MnO}_{2}$ nanosheets on fiberglass for $\mathrm{pH}$-dependent degradation of methylene blue. J. Phys. Chem. Solids 2015, 83, 40-46. [CrossRef]

89. Pandit, A.A.; Pawar, R.A.; Shinde, D.R. Colloidal $\mathrm{MnO}_{2}$ catalyzed degradation of two azo dyes methyl red and methyl orange from aqueous medium. Int. J. Eng. Res. 2013, 4, 1119-1122.

90. Liu, Y.; Chen, Z.; Shek, C.H.; Wu, C.M.L.; Lai, J.K.L. Hierarchical Mesoporous $\mathrm{MnO}_{2}$ Superstructures Synthesized by Soft-Interface Method and Their Catalytic Performances. ACS Appl. Mater. Interfaces 2014, 6, 9776-9784. [CrossRef]

91. Ranjit, K.T.; Willner, I.; Bossmann, S.; Braun, A. Iron(III) Phthalocyanine-Modified Titanium Dioxide: A Novel Photocatalyst for the Enhanced Photodegradation of Organic Pollutants. J. Phys. Chem. B 1998, 102, 9397-9403. [CrossRef]

92. Iliev, V. Phthalocyanine-modified titania-Catalyst for photooxidation of phenols by irradiation with visible light. J. Photochem. Photobiol. A: Chem. 2002, 151, 195-199. [CrossRef] 
93. Mele, G.; Sole, R.D.; Vasapollo, G.; García-López, E.; Palmisano, L.; Schiavello, M. Photocatalytic degradation of 4-nitrophenol in aqueous suspension by using polycrystalline $\mathrm{TiO}_{2}$ impregnated with functionalized $\mathrm{Cu}(\mathrm{II})$-porphyrin or $\mathrm{Cu}(\mathrm{II})-\mathrm{phthalocyanine}$. J. Catal. 2003, 217, 334-342. [CrossRef]

94. Yu, J.C.; Xie, Y.; Tang, H.Y.; Zhang, L.; Chan, H.C.; Zhao, J. Visible light-assisted bactericidal effect of metalphthalocyaninesensitized titanium dioxide films. J. Photochem. Photobiol. A Chem. 2003, 156, 235-241. [CrossRef]

95. Kumar, S.G.; Devi, L.G. Review on Modified $\mathrm{TiO}_{2}$ Photocatalysis under UV/Visible Light: Selected Results and Related Mechanisms on Interfacial Charge Carrier Transfer Dynamics. J. Phys. Chem. A 2011, 115, 13211-13241. [CrossRef] [PubMed]

96. Linsebigler, A.L.; Lu, G.; Yates, J.T., Jr. Photocatalysis on $\mathrm{TiO}_{2}$ Surfaces: Principles, Mechanisms, and Selected Results. Chem. Rev. 1995, 95, 735-758. [CrossRef]

97. Shang, J.; Yao, W.; Zhu, Y.; Wu, N. Structure and photocatalytic performances of glass $/ \mathrm{SnO}_{2} / \mathrm{TiO}_{2}$ interface composite film. Appl. Catal. A Gen. 2004, 257, 25-32. [CrossRef]

98. Shi, L.; Li, C.; Gu, H.; Fang, D. Morphology and properties of ultrafine $\mathrm{SnO}_{2}-\mathrm{TiO}_{2}$ coupled semiconductor particles. Mater. Chem. Phys. 2000, 62, 62-67. [CrossRef]

99. Omrani, N.; Nezamzadeh-Ejhieh, A. A comprehensive study on the enhanced photocatalytic activity of $\mathrm{Cu}_{2} \mathrm{O} / \mathrm{BiVO}_{4} / \mathrm{WO}_{3}$ nanoparticles. J. Photochem. Photobiol. A 2020, 389, 112223. [CrossRef]

100. Khalid, N.R.; Bilal, M.; Tahir, M.B.; Shakil, M.; Iqbal, T.; Rafique, M.; Yousaf, N.; Gillani, S.S.A. Interfacial coupling effect of Ag $2 \mathrm{O}$ nanorods over $\mathrm{MoS}_{2}$ microflowers for improved photocatalytic activity. Ceram. Int. 2020, 46, 6856-6859. [CrossRef]

101. Irie, H.; Watanabe, Y.; Hashimoto, K. Nitrogen-Concentration Dependence on Photocatalytic Activity of TiO ${ }_{2}-\mathrm{xNx}$ Powders. J. Phys. Chem. B 2003, 107, 5483-5486. [CrossRef]

102. Asahi, R.; Morikawa, T.; Ohwaki, T.; Aoki, K.; Taga, Y. Visible-light photocatalysis in nitrogen-doped titanium oxides. Science 2001, 293, 269-271. [CrossRef]

103. Wu, T.; Liu, G.; Zhao, J.; Hidaka, H.; Serpone, N. Evidence for $\mathrm{H}_{2} \mathrm{O}_{2}$ Generation during the $\mathrm{TiO}_{2}$-Assisted Photodegradation of Dyes in Aqueous Dispersions under Visible Light Illumination. J. Phys. Chem. B 1999, 103, 4862-4867. [CrossRef]

104. Belhekar, A.A.; Awate, S.V.; Anand, R. Photocatalytic activity of titania modified mesoporous silica for pollution control. Catal. Commun. 2002, 3, 453-458. [CrossRef]

105. Scaria, J.; Nidheesh, P.V.; Kumar, M.S. Synthesis and applications of various bimetallic nanomaterials in water and wastewater treatment. J. Environ. Manag. 2020, 259, 110011. [CrossRef]

106. Mahmood, M.A.; Baruah, S.; Dutta, J. Enhanced visible light photocatalysis by manganese doping or rapid crystallization with ZnO nanoparticles. Mater. Chem. Phys. 2011, 130, 531-535. [CrossRef]

107. Deka, S.; Joy, P.A. Synthesis and magnetic properties of Mn doped ZnO nanowires. Solid State Commun. 2007, 142, 190-194. [CrossRef]

108. Bhati, I.; Sharma, J.; Ameta, A.; Ameta, S.C. Synthesis and characterization of nanosized $\mathrm{CeCr}_{2} \mathrm{O}_{5}$ and its use as a photocatalyst. Int. J. Chem. Sci. 2011, 9, 1787-1796.

109. Liu, Y.; Sun, D. Effect of $\mathrm{CeO}_{2}$ doping on catalytic activity of $\mathrm{Fe}_{2} \mathrm{O}_{3} / \gamma-\mathrm{Al}_{2} \mathrm{O}_{3}$ catalyst for catalytic wet peroxide oxidation of azo dyes. J. Hazard. Mater. 2007, 143, 448-454. [CrossRef]

110. Saravanan, R.; Karthikeyan, N.; Govindan, S.; Narayanan, V.; Stephen, A. Photocatalytic degradation of organic dyes using $\mathrm{ZnO} / \mathrm{CeO}_{2}$ nanocomposite material under visible light. Adv. Mat. Res. 2012, 584, 381-385.

111. Yang, X.; Wang, Y.; Xu, L.; Yu, X.; Guo, Y. Silver and Indium Oxide Codoped $\mathrm{TiO}_{2}$ Nanocomposites with Enhanced Photocatalytic Activity. J. Phys. Chem. C 2008, 112, 11481-11489. [CrossRef]

112. Georgekutty, R.; Seery, M.K.; Pillai, S.C. A Highly Efficient Ag-ZnO Photocatalyst: Synthesis, Properties, and Mechanism. J. Phys. Chem. C 2008, 112, 13563-13570. [CrossRef]

113. Ganesan, M.; Viswanathan, B.; Viswanath, R.P.; Varadarajan, T.K. Photocatalytic behavior of $\mathrm{CeO}_{2}-\mathrm{TiO}_{2}$ system for the degradation of methylene blue. Indian J. Chem. 2009, 48, 480-488.

114. Xu, D.; Cheng, F.; Lu, Q.; Dai, P. Microwave Enhanced Catalytic Degradation of Methyl Orange in Aqueous Solution over $\mathrm{CuO} / \mathrm{CeO}_{2}$ Catalyst in the Absence and Presence of $\mathrm{H}_{2} \mathrm{O}_{2}$. Ind. Eng. Chem. Res. 2014, 53, 2625-2632. [CrossRef]

115. Tung, W.S.; Daoud, W.A. New approach toward nanosized ferrous ferric oxide and $\mathrm{Fe}_{3} \mathrm{O}_{4}$-doped titanium dioxide photocatalysts. ACS Appl. Mater. Interfaces 2009, 1, 2453-2461. [CrossRef] [PubMed]

116. Zhu, J.; Zheng, W.; Hea, B.; Jhang, J.; Anpo, M. Characterization of Fe-TiO 2 photocatalysts synthesized by hydrothermal method and their photocatalytic reactivity for photodegradation of XRG dye diluted in water. J. Mol. Catal. A Chem. 2004, 216, 35-43. [CrossRef]

117. Zhang, L.; Lian, J.; Wu, L.; Duan, Z.; Jiang, J.; Zhao, L. Synthesis of a Thin-Layer $\mathrm{MnO}_{2} \mathrm{Nanosheet-Coated} \mathrm{Fe}_{3} \mathrm{O}_{4} \mathrm{Nanocomposite}$ as a Magnetically Separable Photocatalyst. Langmuir 2014, 30, 7006-7013. [CrossRef] [PubMed]

118. Sreethawong, T.; Ngamsinlapasathian, S.; Yoshikawa, S. Surfactant-aided sol-gel synthesis of mesoporous-assembled $\mathrm{TiO}_{2}-\mathrm{NiO}$ mixed oxide nanocrystals and their photocatalytic azo dye degradation activity. Chem. Eng. J. 2012, 192, 292-300. [CrossRef]

119. Sreethawong, T.; Yoshikawa, S. Impact of photochemically deposited monometallic Pt and bimetallic Pt-Au nanoparticles on photocatalytic dye-sensitized $\mathrm{H}_{2}$ production activity of mesoporous-assembled $\mathrm{TiO}_{2}-\mathrm{SiO}_{2}$ mixed oxide nanocrystal. Chem. Eng. J. 2012, 197, 272-282. [CrossRef]

120. Mohamed, R.M.; Mkhalid, I.A.; Baeissa, E.S.; Al-Rayyani, M.A. Photocatalytic Degradation of $\mathrm{Methylene} \mathrm{Blue} \mathrm{by} \mathrm{Fe/ZnO/SiO}_{2}$ Nanoparticles under Visible light. J. Nanotechnol. 2012, 2012, 329082. 
121. Xue, M.; Huang, L.; Wang, J.Q.; Wang, Y.; Gao, L.; Zhu, J.H.; Zhou, Z.G. The direct synthesis of mesoporous structured $\mathrm{MnO}_{2} / \mathrm{TiO}_{2}$ nanocomposite: A novel visible-light active photocatalyst with large pore size. Nanotechnology 2008, 19, 185604. [CrossRef]

122. Wang, C.; Shao, C.; Zhang, X.; Liu, Y. $\mathrm{SnO}_{2}$ Nanostructures- $\mathrm{TiO}_{2}$ Nanofibers Heterostructures: Controlled Fabrication and High Photocatalytic Properties. Inorg. Chem. 2009, 48, 7261-7268. [CrossRef] [PubMed]

123. Li, H.B.; Song, Y.D.; Chen, S.G. Preparation and Characterization of $\mathrm{MnO}_{2}$ Loaded CuO Nanosheets. Adv. Mat. Res. 2013, 652-654, 241-244.

124. Qian, K.; Qian, Z.X.; Hua, Q.; Jiang, Z.Q.; Huang, W.X. Structure-activity relationship of $\mathrm{CuO} / \mathrm{MnO}_{2}$ catalysts in $\mathrm{CO}$ oxidation. Appl. Surf. Sci. 2013, 273, 357-363. [CrossRef]

125. Yang, Z.; Yang, Y.; Zhu, X.; Chen, G.; Zhang, W. An Outward Coating Route to $\mathrm{CuO} / \mathrm{MnO}_{2}$ Nanorod Array Films and Their Efficient Catalytic Oxidation of Acid Fuchsin Dye. Ind. Eng. Chem. Res. 2014, 53, 9608-9615. [CrossRef]

126. Guo, Y.; Yang, X.; Ma, F.; Li, K.; Xu, L.; Yuan, X.; Guo, Y. Additive-free controllable fabrication of bismuth vanadates and their photocatalytic activity toward dye degradation. Appl. Surf. Sci. 2010, 256, 2215-2222. [CrossRef]

127. Shang, M.; Wang, W.; Zhou, L.; Sun, S.; Yin, W. Nanosized $\mathrm{BiVO}_{4}$ with high visible-light-induced photocatalytic activity: Ultrasonic-assisted synthesis and protective effect of surfactant. J. Hazard. Mater. 2009, 172, 338-344. [CrossRef]

128. Yin, W.; Wang, W.; Zhou, L.; Sun, S.; Zhang, L. CTAB-assisted synthesis of monoclinic $\mathrm{BiVO}_{4}$ photocatalyst and its highly efficient degradation of organic dye under visible-light irradiation. J. Hazard. Mater. 2009, 173, 194-199. [CrossRef]

129. Ghorai, T.K.; Dhak, D.; Dalai, S.; Pramanik, P. Preparation and photocatalytic activity of nano-sized nickel molybdate $\left(\mathrm{NiMoO}_{4}\right)$ doped bismuth titanate $\left(\mathrm{Bi}_{2} \mathrm{Ti}_{4} \mathrm{O}_{11}\right)$ (NMBT) composite. J. Alloys Compd. 2008, 463, 390-397. [CrossRef]

130. Cruz, A.M.L.; Alfaro, S.O. Synthesis and characterization of $\gamma-\mathrm{Bi}_{2} \mathrm{MoO}_{6}$ prepared by co-precipitation: Photoassisted degradation of organic dyes under vis-irradiation. J. Mol. Catal. A Chem. 2010, 320, 85-91. [CrossRef]

131. Xu, X.; Ni, Q. Synthesis and characterization of novel $\mathrm{Bi}_{2} \mathrm{MoO}_{6} / \mathrm{NaY}$ materials and photocatalytic activities under visible light irradiation. Catal. Commun. 2010, 11, 359-363. [CrossRef]

132. Sahoo, P.P.; Sumithra, S.; Madras, G.; Row, T.N.G. Synthesis, structure and photocatalytic properties of $\beta-\mathrm{ZrMo}_{2} \mathrm{O}_{8}$. Bull. Mater. Sci. 2009, 32, 337-342. [CrossRef]

133. Mulla, I.S.; Natarajan, N.; Gaikwad, A.B.; Samuel, V.; Guptha, U.N.; Ravi, V. A coprecipitation technique to prepare CoTa $2 \mathrm{O}_{6}$ and $\mathrm{CoNb}_{2} \mathrm{O}_{6}$. Mater. Lett. 2007, 61, 2127-2129. [CrossRef]

134. Machida, M.; Yabunaka, J.; Kijima, T. Synthesis and Photocatalytic Property of Layered Perovskite Tantalates, $\mathrm{RbLnTa}_{2} \mathrm{O}_{7}(\mathrm{Ln}=$ La, Pr, Nd, and Sm). Chem. Mater. 2000, 12, 812-817. [CrossRef]

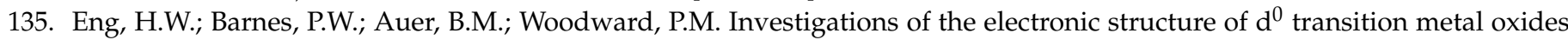
belonging to the perovskite family. J. Solid State Chem. 2003, 175, 94-109. [CrossRef]

136. Ullah, R.; Sun, H.; Ang, H.M.; Tadé, M.O.; Wang, S. Visible light photocatalytic degradation of organics on nanoparticles of bi-metallic oxides. Sep. Purify. Technol. 2012, 89, 98-106. [CrossRef]

137. Su, S.; Guo, W.; Leng, Y.; Yi, C.; Ma, Z. Heterogeneous activation of Oxone by $\mathrm{Co}_{x} \mathrm{Fe}_{3-\mathrm{x}} \mathrm{O}_{4}$ nanocatalysts for degradation of rhodamine B. J. Hazard. Mater. 2013, 244-245, 736-742. [CrossRef] [PubMed]

138. Yu, K.; Yang, S.; He, H.; Sun, C.; Gu, C.; Ju, Y. Visible light-driven photocatalytic degradation of rhodamine $\mathrm{B}$ over $\mathrm{NaBiO}_{3}$ : Pathways and mechanism. J. Phys. Chem. A 2009, 113, 10024-10032. [CrossRef]

139. Li, S.J.; Ma, Z.; Wang, L.; Liu, J. Influence of $\mathrm{MnO}_{2}$ on the photocatalytic activity of $\mathrm{P}-25 \mathrm{TiO}_{2}$ in the degradation of methyl orange. Sci. China Ser. B Chem. 2008, 51, 179-185. [CrossRef]

140. Ahuja, P.; Ujjain, S.K.; Sharma, R.K.; Singh, G. Enhanced supercapacitor performance by incorporating nickel in manganese oxide. RSC Adv. 2014, 4, 57192-57199. [CrossRef]

141. Ahuja, P.; Sharma, R.K.; Singh, G. Solid-state, high-performance supercapacitor using graphene nanoribbons embedded with zinc manganite. J. Mater. Chem. A 2015, 3, 4931-4937. [CrossRef]

142. Ujjain, S.K.; Ahuja, P.; Sharma, R.K. Graphene nanoribbon wrapped cobalt manganite nanocubes for high performance all-solidstate flexible supercapacitors. J. Mater. Chem. A 2015, 3, 9925-9931. [CrossRef]

143. Ahuja, P.; Sahu, V.; Ujjain, S.K.; Sharma, R.K.; Singh, G. Performance evaluation of Asymmetric Supercapacitor based on Cobalt manganite modified graphene nanoribbons. Electrochim. Acta 2014, 146, 429-436. [CrossRef]

144. Ahuja, P.; Ujjain, S.K.; Kanojia, R. Electrochemical behaviour of manganese \& ruthenium mixed oxide@ reduced graphene oxide nanoribbon composite in symmetric and asymmetric supercapacitor. Appl. Surf. Sci. 2018, 427, 102-111.

145. Deori, K.; Ujjain, S.K.; Sharma, R.K.; Deka, S. Morphology Controlled Synthesis of Nanoporous $\mathrm{Co}_{3} \mathrm{O}_{4} \mathrm{Nanostructures}$ and Their Charge Storage Characteristics in Supercapacitors. ACS Appl. Mater. Interfaces 2013, 5, 10665-10672. [CrossRef]

146. Stoyanova, M.; Slavova, I.; Christoskova, S.; Ivanova, V. Catalytic performance of supported nanosized cobalt and iron-cobalt mixed oxides on $\mathrm{MgO}$ in oxidative degradation of Acid Orange 7 azo dye with peroxymonosulfate. Appl. Catal. A Gen. 2014, 476, 121-132. [CrossRef]

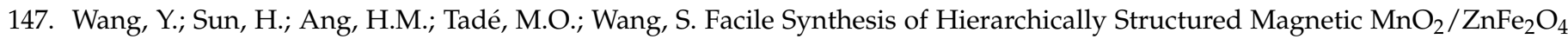
Hybrid Materials and Their Performance in Heterogeneous Activation of Peroxymonosulfate. ACS Appl. Mater. Interfaces 2014, 6, 19914-19923. [CrossRef]

148. Sathishkumar, P.; Mangalaraja, R.V.; Anandan, S.; Ashokkumar, M. $\mathrm{CoFe}_{2} \mathrm{O}_{4} / \mathrm{TiO}_{2}$ nanocatalysts for the photocatalytic degradation of Reactive Red 120 in aqueous solutions in the presence and absence of electron acceptors. Chem. Eng. J. 2013, 220, 302-310. [CrossRef] 
149. Cui, B.; Lin, H.; Liu, Y.; Li, J.; Sun, P.; Zhao, X.; Liu, C. Photophysical and Photocatalytic Properties of Core-Ring Structured $\mathrm{NiCo}_{2} \mathrm{O}_{4}$ Nanoplatelets. J. Phys. Chem. C 2009, 113, 14083-14087. [CrossRef]

150. Singh, M.K.; Patra, A. Highly efficient and Reusable ZnO microflower photocatalyst on stainless steel mesh under UV-Vis and natural sunlight. Opt. Mater. 2020, 107, 110000. [CrossRef]

151. Basnet, P.; Samanta, D.; Chanu, T.I.; Chatterjee, S. Visible light facilitated degradation of alternate dye solutions by highly reusable Mn-ZnO nano-photocatalyst. J. Alloys Compd. 2021, 867, 158870. [CrossRef]

152. Sharma, S.; Basu, S. Highly reusable visible light active hierarchical porous $\mathrm{WO}_{3} / \mathrm{SiO}_{2}$ monolith in centimeter length scale for enhanced photocatalytic degradation of toxic pollutants. Sep. Purif. Technol. 2020, 231, 115916. [CrossRef]

153. Janitabar-Darzi, S.; Mahjoub, A.R. Investigation of phase transformations and photocatalytic properties of sol-gel prepared nanostructured $\mathrm{ZnO} / \mathrm{TiO}_{2}$ composites. J. Alloys Compd. 2009, 486, 805-808. [CrossRef]

154. Sajjad, A.K.L.; Shamaila, S.; Tian, B.; Chen, F.; Zhang, J. Comparative studies of operational parameters of degradation of azo dyes in visible light by highly efficient $\mathrm{WO}_{x} / \mathrm{TiO}_{2}$ photocatalyst. J. Hazard. Mater. 2010, 177, 781-791. [CrossRef]

155. Ghasemi, S.; Rahimnejad, S.; Setayesh, S.R.; Rohani, S.; Golami, M.R. Transition metal ions effect on the properties and photocatalytic activity of nanocrystalline $\mathrm{TiO}_{2}$ prepared in an ionic liquid. J. Hazard. Mater. 2009, 172, 1573-1578. [CrossRef]

156. Shen, W.; Li, Z.; Wang, H.; Liu, Y.; Guo, Q.; Zhang, Y. Photocatalytic degradation for methylene blue using zinc oxide prepared by codeposition and sol-gel methods. J. Hazard. Mater. 2008, 152, 172-175. [CrossRef]

157. Singh, J.; Rathi, A.; Rawat, M.; Kumar, V.; Kim, K.-H. The effect of manganese doping on structural, optical, and photocatalytic activity of zinc oxide nanoparticles. Compos. B. Eng. 2019, 166, 361-370. [CrossRef]

158. Xu, C.; Wei, X.; Guo, Y.; Wu, H.; Ren, Z.; Xu, G.; Shen, G.; Han, G. Surfactant-free synthesis of $\mathrm{Bi}_{2} \mathrm{WO}_{6}$ multilayered disks with visible-light-induced photocatalytic activity. Mater. Res. Bull. 2009, 44, 1635-1641. [CrossRef]

159. Lin, S.; Chen, J.; Weng, X.; Yang, L.; Chen, X. Fabrication and photocatalysis of mesoporous $\mathrm{ZnWO}_{4}$ with PAMAM as a template. Mater. Res. Bull. 2009, 44, 1102-1105. [CrossRef]

160. Seddigi, Z.S. Removal of Alizarin Yellow Dye from Water Using Zinc Doped $\mathrm{WO}_{3}$ Catalyst. Bull. Environ. Contam. Toxicol. 2010, 84, 564-567. [CrossRef] [PubMed]

161. Cho, I.; Kwak, C.H.; Kim, D.W.; Lee, S.; Hong, K.S. Photophysical, Photoelectrochemical, and Photocatalytic Properties of Novel $\mathrm{SnWO}_{4}$ Oxide Semiconductors with Narrow Band Gaps. J. Phys. Chem. C 2009, 113, 10647-10653. [CrossRef]

162. Ahmad, M.; Ahmed, E.; Ahmed, W.; Elhissi, A.; Hong, Z.L.; Khalid, N.R. Enhancing visible light responsive photocatalytic activity by decorating Mn-doped ZnO nanoparticles on graphene. Ceram. Int. 2014, 40, 10085-10097. [CrossRef]

163. Ahuja, P.; Ujjain, S.K.; Kanojia, R. MnOx/C nanocomposite: An insight on high-performance supercapacitor and non-enzymatic hydrogen peroxide detection. Appl. Surf. Sci. 2017, 404, 197-205. [CrossRef]

164. Ujjain, S.K.; Sahu, V.; Sharma, R.K.; Singh, G. High performance, all solid state, flexible supercapacitor based on ionic liquid functionalized graphene. Electrochim. Acta 2015, 157, 245-251. [CrossRef]

165. Ujjain, S.K.; Ahuja, P.; Sharma, R.K. Facile preparation of graphene nanoribbon/cobalt coordination polymer nanohybrid for non-enzymatic $\mathrm{H}_{2} \mathrm{O}_{2}$ sensing by dual transduction: Electrochemical and fluorescence. J. Mater. Chem. B 2015, 3, 7614-7622. [CrossRef]

166. Putri, A.D.; Chotimah, N.; Ujjain, S.K.; Wang, S.; Futamura, R.; Vallejos-Burgos, F.; Khoerunnisa, F.; Morimoto, M.; Wang, Z.; Hattori, Y.; et al. Charge-transfer mediated nanopore-controlled pyrene derivatives/graphene colloids. Carbon 2018, 139, 512-521. [CrossRef]

167. Ujjain, S.K.; Sharma, R.K.; Singh, G. $\mathrm{Co}_{3} \mathrm{O}_{4} @$ reduced graphene oxide nanoribbon for high performance asymmetric supercapacitor. Electrochim. Acta 2015, 169, 276-282. [CrossRef]

168. Ujjain, S.K.; Bagusetty, A.; Matsuda, Y.; Tanaka, H.; Ahuja, P.; De Tomas, C.; Sakai, M.; Vallejos-Burgos, F.; Futamura, R.; SuarezMartinez, I.; et al. Adsorption separation of heavier isotope gases in subnanometer carbon pores. Nat. Commun. 2021, 12, 546. [CrossRef] [PubMed]

169. Li, Y.; Zhang, S.; Yu, Q.; Yin, W. The effects of activated carbon support on the structure and properties of $\mathrm{TiO}_{2}$ nanoparticles prepared by a sol-gel method. Appl. Surf. Sci. 2007, 253, 9254-9258. [CrossRef]

170. Wang, X.; Hu, Z.; Chen, Y.; Zhao, G.; Liu, Y.; Wen, Z. A novel approach towards high-performance composite photocatalyst of $\mathrm{TiO}_{2}$ deposited on activated carbon. Appl. Surf. Sci. 2009, 255, 3953-3958. [CrossRef]

171. Zhang, X.; Zhou, M.; Lei, L. Preparation of photocatalytic $\mathrm{TiO}_{2}$ coatings of nanosized particles on activated carbon by AP-MOCVD. Carbon 2005, 43, 1700-1708. [CrossRef]

172. Zhang, X.; Zhou, M.; Lei, L. TiO 2 photocatalyst deposition by MOCVD on activated carbon. Carbon 2006, 44, 325-333. [CrossRef]

173. Ao, Y.; Xu, J.; Fu, D.; Yuan, C. A simple route for the preparation of anatase titania-coated magnetic porous carbons with enhanced photocatalytic activity. Carbon 2008, 46, 596-603. [CrossRef]

174. Velasco, L.F.; Ania, C.O. Role of activated carbon features on the photocatalytic degradation of phenol. Appl. Surf. Sci. 2010, 256, 5254-5258. [CrossRef]

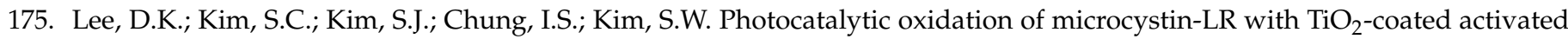
carbon. Chem. Eng. J. 2004, 102, 93-98. [CrossRef]

176. Yao, Y.; Li, G.; Ciston, S.; Lueptow, R.M.; Gray, K.A. Photoreactive $\mathrm{TiO}_{2}$ / carbon nanotube composites: Synthesis and reactivity. Environ. Sci. Technol. 2008, 42, 4952-4957. [CrossRef] 
177. Ahmmad, B.; Kusumoto, Y.; Somekawa, S.; Ikeda, M. Carbon nanotubes synergistically enhance photocatalytic activity of TiO 2 . Catal. Commun. 2008, 9, 1410-1413. [CrossRef]

178. Xia, X.H.; Jia, Z.J.; Yu, Y.; Liang, Y.; Wang, Z.; Ma, L.L. Preparation of multi-walled carbon nanotube supported TiO 2 and its photocatalytic activity in the reduction of $\mathrm{CO}_{2}$ with $\mathrm{H}_{2} \mathrm{O}$. Carbon 2007, 45, 717-721. [CrossRef]

179. Hoffmann, M.R.; Martin, S.T.; Choi, W.; Bahnemann, D.W. Environmental Applications of Semiconductor Photocatalysis. Chem. Rev. 1995, 95, 69-96. [CrossRef]

180. Liu, B.; Zeng, H.C. Carbon Nanotubes Supported Mesoporous Mesocrystals of Anatase $\mathrm{TiO}_{2}$. Chem. Mater. 2008, 20, $2711-2718$. [CrossRef]

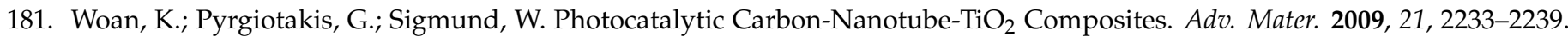
[CrossRef]

182. Xiong, P.; Fu, Y.; Wang, L.; Wang, X. Multi-walled carbon nanotubes supported nickel ferrite: A magnetically recyclable photocatalyst with high photocatalytic activity on degradation of phenols. Chem. Eng. J. 2012, 195-196, 149-157. [CrossRef]

183. Fan, W.; Lai, Q.; Zhang, Q.; Wang, Y. Nanocomposites of $\mathrm{TiO}_{2}$ and Reduced Graphene Oxide as Efficient Photocatalysts for Hydrogen Evolution. J. Phys. Chem. C 2011, 115, 10694-10701. [CrossRef]

184. Li, N.; Liu, C.; Zhen, C.; Li, F.; Zhang, L.; Cheng, H.M. Battery Performance and Photocatalytic Activity of Mesoporous Anatase $\mathrm{TiO}_{2}$ Nanospheres/Graphene Composites by Template-Free Self-Assembly. Adv. Funct. Mater. 2011, 21, 1717-1722. [CrossRef]

185. Xiang, Q.; Yu, J.; Jaroniec, M. Graphene-based semiconductor photocatalysts. Chem. Soc. Rev. 2012, 41, 782-796. [CrossRef] [PubMed]

186. Li, B.; Cao, H. ZnO@graphene composite with enhanced performance for the removal of dye from water. J. Mater. Chem. 2011, 21, 3346-3349. [CrossRef]

187. Zhang, J.; Xiong, Z.; Zhao, X.S. Graphene-metal-oxide composites for the degradation of dyes under visible light irradiation. J. Mater. Chem. 2011, 21, 3634-3640. [CrossRef]

188. Du, J.; Lai, X.; Yang, N.; Zhai, J.; Kisailus, D.; Su, F.; Wang, D.; Jiang, L. Hierarchically ordered macro-mesoporous TiO ${ }_{2}$-graphene composite films: Improved mass transfer, reduced charge recombination, and their enhanced photocatalytic activities. ACS Nano 2011, 5, 590-596. [CrossRef]

189. Chen, J.S.; Wang, Z.; Dong, X.C.; Chena, P.; Lou, X.W.D. Graphene-wrapped $\mathrm{TiO}_{2}$ hollow structures with enhanced lithium storage capabilities. Nanoscale 2011, 3, 2158-2161. [CrossRef] [PubMed]

190. Wang, D.; Hoi, D.; Li, J.; Yang, Z.; Nie, Z.; Kou, R.; Hu, D.; Wang, C.; Saraf, L.V.; Zhang, J.; et al. Self-Assembled TiO $2-$ Graphene Hybrid Nanostructures for Enhanced Li-Ion Insertion. ACS Nano 2009, 3, 907-914. [CrossRef]

191. Park, Y.; Kang, S.; Choi, W. Exfoliated and reorganized graphite oxide on titania nanoparticles as an auxiliary co-catalyst for photocatalytic solar conversion. Phys. Chem. Chem. Phys. 2011, 13, 9425-9431. [CrossRef]

192. Fu, Y.; Wang, X. Magnetically Separable $\mathrm{ZnFe}_{2} \mathrm{O}_{4}-$ Graphene Catalyst and its High Photocatalytic Performance under Visible Light Irradiation. Ind. Eng. Chem. Res. 2011, 50, 7210-7218. [CrossRef]

193. Mukherji, A.; Seger, B.; Lu, G.Q.M.; Wang, L. Nitrogen Doped $\mathrm{Sr}_{2} \mathrm{Ta}_{2} \mathrm{O}_{7}$ Coupled with Graphene Sheets as Photocatalysts for Increased Photocatalytic Hydrogen Production. ACS Nano 2011, 5, 3483-3492. [CrossRef]

194. Shen, J.; Yan, B.; Shi, M.; Ma, H.; Lia, N.; Ye, M. One step hydrothermal synthesis of $\mathrm{TiO}_{2}$-reduced graphene oxide sheets. J. Mater. Chem. 2011, 21, 3415-3421. [CrossRef]

195. Williams, G.; Seger, B.; Kamat, P.V. TiO 2 -Graphene Nanocomposites. UV-Assisted Photocatalytic Reduction of Graphene Oxide. ACS Nano 2008, 2, 1487-1491. [CrossRef]

196. Williams, G.; Kamat, P.V. Graphene-semiconductor nanocomposites: Excited-state interactions between ZnO nanoparticles and graphene oxide. Langmuir 2009, 25, 13869-13873. [CrossRef] [PubMed]

197. Kamat, P.V. Graphene-Based Nanoarchitectures. Anchoring Semiconductor and Metal Nanoparticles on a Two-Dimensional Carbon Support. J. Phys. Chem. Lett. 2010, 1, 520-527. [CrossRef]

198. Lightcap, I.V.; Kosel, T.H.; Kamat, P.V. Anchoring Semiconductor and Metal Nanoparticles on a Two-Dimensional Catalyst Mat. Storing and Shuttling Electrons with Reduced Graphene Oxide. Nano Lett. 2010, 10, 577-583. [CrossRef]

199. Liu, J.; Bai, H.; Wang, Y.; Liu, Z.; Zhang, X.; Sun, D.D. Self-Assembling $\mathrm{TiO}_{2}$ Nanorods on Large Graphene Oxide Sheets at a Two-Phase Interface and Their Anti-Recombination in Photocatalytic Applications. Adv. Funct. Mater. 2010, $23,4175-4181$. [CrossRef]

200. Zhou, K.; Zhu, Y.; Yang, X.; Jianga, X.; Lia, C. Preparation of graphene-TiO ${ }_{2}$ composites with enhanced photocatalytic activity. New J. Chem. 2011, 35, 353-359. [CrossRef]

201. Yao, Y.; Yang, Z.; Sun, H.; Wang, S. Hydrothermal Synthesis of $\mathrm{Co}_{3} \mathrm{O}_{4}$-Graphene for Heterogeneous Activation of Peroxymonosulfate for Decomposition of Phenol. Ind. Eng. Chem. Res. 2012, 51, 14958-14965. [CrossRef]

202. Yao, Y.; Xu, C.; Yu, S.; Zhang, D.; Wang, S. Facile Synthesis of $\mathrm{Mn}_{3} \mathrm{O}_{4}$-Reduced Graphene Oxide Hybrids for Catalytic Decomposition of Aqueous Organics. Ind. Eng. Chem. Res. 2013, 52, 3637-3645. [CrossRef]

203. Zhang, H.; Lv, X.; Li, Y.; Wang, Y.; Li, J. P25-Graphene Composite as a High Performance Photocatalyst. ACS Nano 2010, 4, 380-386. [CrossRef] [PubMed]

204. Fatima, R.; Warsi, M.F.; Zulfiqar, S.; Ragab, S.A.; Shakir, I.; Sarwar, M.I. Nanocrystalline transition metal oxides and their composites with reduced graphene oxide and carbon nanotubes for photocatalytic applications. Ceram. Int. 2020, 46, 16480-16492. [CrossRef] 
205. Zhang, Y.; Tang, Z.; Fu, X.; Xu, Y. TiO 2 -Graphene Nanocomposites for Gas-Phase Photocatalytic Degradation of Volatile Aromatic Pollutant: $\mathrm{Is}_{\mathrm{TiO}_{2}}-$ Graphene Truly Different from Other $\mathrm{TiO}_{2}-$ Carbon Composite Materials. ACS Nano 2010, 4, 7303-7314. [CrossRef] [PubMed]

206. Bai, X.; Wang, L.; Zong, R.; Lv, Y.; Sun, Y.; Zhu, Y. Performance Enhancement of ZnO Photocatalyst via Synergic Effect of Surface Oxygen Defect and Graphene Hybridization. Langmuir 2013, 29, 3097-3105. [CrossRef]

207. Li, X.; Yang, S.; Sun, J.; He, P.; Xu, X.; Ding, G. Tungsten oxide nanowire-reduced graphene oxide aerogel for high-efficiency visible light photocatalysis. Carbon 2014, 78, 38-48. [CrossRef]

208. Qu, J.; Shi, L.; He, C.; Gao, F.; Li, B.; Zhou, Q.; Hu, H.; Shao, G.; Wang, X.; Qiu, J. Highly efficient synthesis of graphene/MnO 2 hybrids and their application for ultrafast oxidative decomposition of methylene blue. Carbon 2014, 66, 485-492. [CrossRef]

209. Rani, S.; Kumar, M.; Sharma, S.; Kumar, D.; Tyagi, S. Effect of Graphene in Enhancing the Photo Catalytic Activity of Zirconium Oxide. Catal. Lett. 2014, 144, 301-307. [CrossRef]

210. Alamelu, K.; Raja, V.; Shiamala, L.; Jaffar Ali, B.M. Biphasic $\mathrm{TiO}_{2}$ nanoparticles decorated graphene nanosheets for visible light driven photocatalytic degradation of organic dyes. Appl. Surf. Sci. 2018, 430, 145-154. [CrossRef]

211. Zhang, R.; Ma, Y.; Lan, W.; Sameen, D.E.; Ahmed, S.; Dai, J.; Qin, W.; Li, S.; Liu, Y. Enhanced photocatalytic degradation of organic dyes by ultrasonic-assisted electrospray $\mathrm{TiO}_{2}$ /graphene oxide on polyacrylonitrile/ $\beta$-cyclodextrin nanofibrous membranes. Ultrason. Sonochem. 2021, 70, 105343. [CrossRef]

212. Nguyen, C.H.; Tran, M.L.; Tran, T.T.V.; Juang, R.-S. Enhanced removal of various dyes from aqueous solutions by UV and simulated solar photocatalysis over $\mathrm{TiO}_{2} / \mathrm{ZnO} / \mathrm{rGO}$ composites. Sep. Purif. Technol. 2020, 232, 115962. [CrossRef]

213. Truong, N.T.; Thi, H.P.N.; Ninh, H.D.; Phung, X.T.; Tran, C.V.; Nguyen, T.T.; Pham, T.D.; Dang, T.D.; Chang, S.W.; Rene, E.R.; et al. Facile fabrication of graphene@Fe-Ti binary oxide nanocomposite from ilmenite ore: An effective photocatalyst for dye degradation under visible light irradiation. J. Water Process. Eng. 2020, 37, 101474. [CrossRef]

214. Chen, C.; Cai, W.; Long, M.; Zhou, B.; Wu, Y.; Wu, D.; Feng, Y. Synthesis of Visible-Light Responsive Graphene Oxide/TiO 2 Composites with $\mathrm{p} / \mathrm{n}$ Heterojunction. ACS Nano 2010, 4, 6425-6432. [CrossRef] [PubMed]

215. Xu, T.G.; Zhang, L.W.; Cheng, H.Y.; Zhu, Y.F. Significantly enhanced photocatalytic performance of ZnO via graphene hybridization and the mechanism study. Appl. Catal. B 2011, 101, 382-387. [CrossRef]

216. Zhu, M.; Chen, P.; Liu, M. Graphene Oxide Enwrapped Ag/AgX (X = Br, Cl) Nanocomposite as a Highly Efficient Visible-Light Plasmonic Photocatalyst. ACS Nano 2011, 5, 4529-4536. [CrossRef] [PubMed]

217. Ng, Y.H.; Iwase, A.; Kudo, A.; Amal, R. Reducing Graphene Oxide on a Visible-Light $\mathrm{BiVO}_{4}$ Photocatalyst for an Enhanced Photoelectrochemical Water Splitting. J. Phys. Chem. Lett. 2010, 1, 2607-2612. [CrossRef]

218. Zhang, X.Y.; Li, H.P.; Cui, X.L.; Lin, Y.H. Graphene $/ \mathrm{TiO}_{2}$ nanocomposites: Synthesis, characterization and application in hydrogen evolution from water photocatalytic splitting. J. Mater. Chem. 2010, 20, 2801-2806. [CrossRef]

219. Zhang, X.; Quan, X.; Chen, S.; Yu, H. Constructing graphene/ $\mathrm{InNbO}_{4}$ composite with excellent adsorptivity and charge separation performance for enhanced visible-light-driven photocatalytic ability. Appl. Catal. B 2011, 105, 237-242. [CrossRef]

220. Luciano, A.J.R.; Soletti, L.D.S.; Ferreira, M.E.C.; Cusioli, L.F.; Andrade, M.B.D.; Bergamasco, R.; Yamaguchi, N.U. Manganese ferrite dispersed over graphene sand composite for methylene blue photocatalytic degradation. J. Environ. Chem. Eng. 2020, 8, 104191. [CrossRef]

221. Gratzel, M. Conversion of sunlight to electric power by nanocrystalline dye-sensitized solar cells. J. Photochem. Photobiol. A 2004, 164, 3-14. [CrossRef]

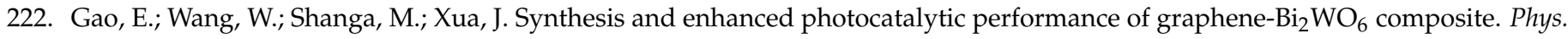
Chem. Chem. Phys. 2011, 13, 2887-2893. [CrossRef] [PubMed]

223. Fu, Y.; Chen, Q.; He, M.; Wan, Y.; Sun, X.; Xia, H.; Wang, X. Copper Ferrite-Graphene Hybrid: A Multifunctional Heteroarchitecture for Photocatalysis and Energy Storage. Ind. Eng. Chem. Res. 2012, 51, 11700-11709. [CrossRef] 